\title{
Socio-Economic Assessment of Religious Tourism in Nigeria
}

\author{
Emmanuel O. Okon ${ }^{1}$ \\ ${ }^{1}$ Department of Economics, Kogi State University, Anyigba, Kogi State, Nigeria \\ Correspondence: Department of Economics, Kogi State University, Anyigba, Kogi State, Nigeria, E-mail: \\ tonydom57@yahoo.com. Tel: +2348023275716
}

Received: January 8, $2018 \quad$ Accepted: January 12, $2018 \quad$ Online Published: January 19, 2018

\begin{abstract}
The purpose of this study is to examine the socio-economic impact of religious tourism in Nigeria. Data for this study are from secondary sources and it covers 2000-2011. The technique of content analysis was used to analyze the contents of these materials. The paper reveals that the springing up of different Pentecostal Churches across the country and the various conventions and festivals being held annually and quarterly by this churches have virtually increase the numbers of arrivals from overseas countries who visit the country to attend various religious programs. This has generated employment for the inhabitants of the areas; religious tourism has become the highest earner of foreign exchange for the country's tourism industry even though tourism industry is still in embryonic stages and has not yet assumed a significant position in Nigeria's GDP pie. This paper recommends that the hospitality industry should upgrade existing facilities while the government should construct or upgrade to international standards roads leading to major cities and rural areas and needs to provide basic amenities in tourism destinations. At the local government level, inventory of all tourist sites and festivals in different localities should be published so as to bring these tourist sites into limelight. All religious communities must educate their clergy on the need for religious harmony and the toleration of other faiths.
\end{abstract}

Keywords: Religion, Festival, Religious Tourism.

\section{Introduction}

The international tourism industry has become a global economic force, generating significant revenues and contributing directly and indirectly to national economies. The World Tourism Organization (WTO) indicates that in 2002, 703 million tourists travelled across international boundaries, generating over US $\$ 474$ billion in revenues. In its tourism growth forecast, Tourism: 2020 Vision, the WTO also predicts that the tourism sector will grow by an average of $4.1 \%$ per year over the next two decades, surpassing a total of 1billion international tourists by the year 2010. Projections for the year 2020 indicate that tourist arrivals will grow to around 1.6 billion with earnings of up to US\$ 2 trillion (Milne and Ateljevic, 2001; Neto, 2002; NEPAD, 2004, p.3). The main reasons for travelling are leisure, businesses, conventions and seminars, meetings, study abroad, religion purposes as well as sports or games. Religious tourism is among the least explored tourist activities in the world of modern tourism. In recent years, religious tourism has been on the increase with a growing number of people visiting historic places in developed countries. This is attributed to the fact that religious obligations has become a fashionable trend all over the world as a means of expressing beliefs and faith in the ability of God to protect and guide mankind. It would amount to stating the most obvious that religious practices both under the auspices of Christianity, Islam and traditional practices have in no small way contributed to the development tourism in the world. It is a known fact the Christian pilgrimages to Israel has formed an economic platform for the empowerment of the localities and contributed to the Gross Domestic Product (GDP) of the country. Also, in the Saudi Arabia, where many Islamic faithful converge twice every year for religious rituals, it has been of tremendous economic benefit to the country and her people. With these scenarios and many others around the world, it has become valid that religious tourism can become a source of economic revival to a country and its people.

Religious tourism is practiced to a considerable degree not only in the developed countries, but also in developing countries insofar as disposable income allows the upper and middle classes to travel (Vukonic, 1998). However, in 
Nigeria, beyond several allusions by government on the promotion of tourism, religion has continued to play a pivotal role in the development of tourism in the country. Many dignitaries have in recent time found Nigeria the essential balm to many of their spiritual problems, with many heads of government visiting Nigeria to seek solution. The growth of religious tourism in Nigeria has been pivoted by Christians, Islam and Traditional believers, through various festivals and programs that have become tourism attractions for many, both within and outside Nigeria (Umejei, 2009),(see appendix for different maps of Nigeria).

Religious tourism is widely considered as an effective contributor to socio-economic development, particularly in less developed countries. However, despite its adoption as a developmental option, the extent to which economic and social development inevitably follows the introduction and promotion of a religious tourism remains the subject of intense debate. In this context, this paper examines the socio-economic impact of religious tourism in Nigeria taking account of the different religions and their festivals, crusades, conventions, revenue generation, employment and impact on local communities. It also contributes in the field of religious tourism management in Nigeria given the influx of people. This paper is important in this period when efforts are geared at rebranding Nigeria through tourism potentials. The image of Nigeria had been battered before the world.This is a country where it is believed that nothing can work well. Nigeria has come to be identified with biblicalaged saying. "Can anything good come out of Nazareth?"(Adebola,Talabi, and Lamidi, 2012).Nigerian evangelical churches are the fastest growing Christian organizations in the world. They are popular all over Africa and in the West. Also, the muslim and traditional religious festivals of Nigeria are internationally visited. To this end, tourism is the best medium for rebranding the country and this can also be achieved through the nation's religions.

To achieve the stated objective, after the introductory part, the second part of the paper addresses conceptual issues while the third part examines religions and festival types in Nigeria. The fourth section explains the methodology and data and technique of analysis. Equally, analysis and discussion are presented in this same section. Policies towards enhancing tourism and hindrances of religious tourism are presented in section five. The final part concludes the paper by suggesting ways of making religious tourism contribute more to sustainable development.

2. Religious Tourism Concept

Religious tourism is a term widely used in theory and practice to refer to contemporary travel patterns to pilgrimage sites. Religious tourism is considered to be a 'specific type of tourism whose participants are motivated either in part or exclusively for religious reasons' (Rinschede, 1992) in such a way that it is 'closely or loosely connected with holiday-making' (Tomasi, 2002). The destination for religious tourism is generally a sacred site, a pilgrimage site or a religious heritage site. It combines two opposite ends of the binary - sacred and profane - as reflected in the pilgrimage-tourism dichotomy (Nolan and Nolan, 1992; Smith, 1992). Often, the key aspects of pilgrimage - the motivation for the trip, form of the journey and a sacred destination - are used to explain religious tourism where leisure and holiday activities occur as supplementary opportunities within the need for religious travel (Tyrakowski, 1994).There is also a tendency to use external aspects such as tour operations, management and packaging of leisure-related activities, along-side pilgrimage, to claim religious tourism as a part of the tourism industry (Tomasi, 2002; Sharpley and Sundaram, 2005). However, most scholars concur that religious tourism is multi-layered and involves multi-functional and multi-purpose trips (Kaur, 1985; Nolan and Nolan, 1992). It simultaneously is a 'niche' market as well as one of the largest contributors to tourist flows.

Many studies have attempted to define and compare religioustourism and pilgrimage (Graburn, 1977; Cohen, 1992; Smith, 1992; Shinde, 2007). Pilgrimage has been traditionally defined as traveling to a shrine or to a place with religious significance with the purpose of performing religious rites and rituals or to fulfill a spiritual need. On the other hand, religious tourists could be motivated by much broader cultural reasons. Another difference between religious tourists and pilgrims, if we accept this classical view, is in behavior during travel. The travel of a pilgrim is characterized by austerity and ritual (Blackwell, 2007) while the behavior of religious tourists resembles both that of pilgrims and tourists (Pusztai, 2004 and Josan, 2009). By taking a spiritual leader on the journey, praying and singing hymns they resemble the pilgrims. However, they reject physical penitence and ascetism, and, similar to tourists, prefer a comfortable journey and good quality accommodation. However, this classic division between pilgrims and religious tourists no longer holds because "contemporary pilgrimages involve such huge numbers of people that they can only be organized in the same manner as mass tourism" (Tomasi, 2002).

Moreover, today many people travel for both religious and recreational reasons and many pilgrimage places have been "secularized" through commercialization and commoditization (Raj, 2008; Shinde, 2007). At many religious sites today you can find also secular tourists who may visit not only to learn more about the place but also to fulfill some personal or spiritual needs (Sharpley\&Sundaram, 2005; Collins-Kreiner, 2010). On the other hand, even deeply religious pilgrims today prefer to use modern means of transportation and stay in hotels, or, at least, require the provision of some services (Nolan \& Nolan, 1992). This would make them, at least partly, tourists. For these reasons, the division between pilgrimage and religious tourism is blurred today. Motivation has become more 
complex with only a fraction of the travelers visiting religious sites for their sacred significance. An increasing number of tourists visit these sites for a range of other reasons, mainly cultural or educational (Sharpley\&Sundaram, 2005). As a matter of fact, for many, religioustourism is part of a broader cultural tourism (Swarbrooke, 1999; Rinschede, 1992). In this study, religioustourism refers to all travel to sites of religious importance motivated, at least partly, by religion (Rinschede, 1992).

It should also be mentioned that religioustourism means not only visiting sites, shrines and structures with religious significance but also attending religious conferences, different cultural-religious events, exhibition of cultic objects, as well as concerts of sacred music. Nolan (1992) distinguishes three types of religious attractions: pilgrimage shrines which have strong religious significance but have little else to attract secular tourists; shrines that attract both pilgrims and more secular tourists because the site is also attractive from a historical, artistic or scenic perspective; sites where the main attraction is represented by religious festivals. The "new" religious tourists are also more likely to visit other tourist objectives while in the area and also make more use of the local hotels, restaurants or local transport which recommends religioustourism as an important economic sector especially for those regions that lack other opportunities for development (Egresi, Bayram, Kara and Kesik, 2012).

A majority of the literature on religious tourism have originated from European countries (Nolan and Nolan, 1992; Rinschede, 1992; Bywater, 1994). The focus in these studiesrange from problems with the definition of the term and its theoretical conceptualization to empirical evidence from religious tourism destinations. Olsen and Timothy (2006) identify four broad themes in these literature: distinguishing the pilgrim from the tourist (tourist-pilgrim dichotomy); the characteristics and travel patterns of religious tourists; the economics of religious tourism; and the negative impacts of tourism on religious sites and ceremonies. While the economic aspects of religious tourism have generated substantial interest, it continues to be under-researched (Timothy and Olsen, 2006).

The present paper contributes to the existing body of literature in number of ways. First unlike most of the past studies that focused on advanced economies the focus is on Nigeria, a developing country in the sub Saharan Africa, which is just launching its tourism master plan in an effort to promote tourism and rebrand the country. Second the study does not only asses the economic impact of religious tourism but also the social aspect.

3. Typology of Religions and Festivals in Nigeria

Nigeria religion comprises a number of religions, mainly Christianity, Islam and the traditional religion of Nigeria. Formerly different ethnic groups of Nigeria practiced different religions, which were finally overpowered by Islam and Christianity. Islam mainly dominated the northern part of Nigeria, while Christianity was prevalent in the southern part of Nigeria, among the Yoruba and the Igbo ethnic groups. Yoruba people inhabiting in Nigeria are mainly practitioners of Protestantism, while Igbo and the groups residing in the nearby areas are followers of Catholicism. Nigeria religion represents Nigerian culture (MYW, 2012), (see appendix for photos of people from each tribe).

In Nigeria, as indeed most West African countries during the mid-twentieth century, there were two main Islamic orders, the Qadriyya and the Tijaniyya. The Quadriyya was firmly linked to the Fulani leadership in Sokoto.On its part, the Tijaniyya was mainly rooted in Kano. Like the Quadriyya, the Tijaniyya too had different sub-sects. Currently, Islam in Nigeriais mostly of the Sunni Maliki sect, with minority Shi'a in Sokoto and some parts of North-West. The traditional sects under the Sunni Islam in Nigeria are the Qadriyya, the Tijaniyya, the Tariqa, the Malikiya, the Ahmadiya and the Islamiyya. Of all these, however, the Quadiyyas and Tijaniyyas are the more prominent. The majority of Northern Nigerian Muslims, especially the commoners, embrace Tijanniya, while the Quadriyyas have more elitist adherents within the society (Alao, 2010).

The typology of Christian groups in Nigeria by Gaiya (2002) identifies Sunday Worshippers and Sabbath Worshippers as churches.This typology is built around the classical Reformation themes of Sola Scriptura and Scriptura et Traditiones. The sola churches are those churches that are founded on the principle of a unique and selfemanating theology developed around national and cultural experiences of the people. These churches are completely African in ecclesiology and unilateral in ministry. They are generally known as Orthodox /Africanist churches.The following congregations represent this typology in Nigeria: United Native African Church, Christ African Church (Bethel), United African Methodist Church, Kingdom of God Church and New Life Church, etc. African nationalism remains the founding and enduring principle of these churches both in doctrine and worship (Ukpong, 2012).

Scriptura churchesidentifying characteristics are the Bible, African spirituality and western theology, particularly health and wealth theology. They demonstrate an immense attraction to the Bible, but the Bible is interpreted from the perspective of African spirituality rapped in the categories of material-well-being of believers in this world. These churches are generally known as Pentecostal / Charismatic churches. Examples of these churches under the classical pentecostalism include: the Apostolic Church of Nigeria, etc. The Neo-pentecostal conglomerations are represented by the Deeper Life Bible Church, the Church of God Mission, the Latter Rain Assemblies, etc. The third 
wavers could be identified with churches or ministries like Household of God of Chris Okotie, Christ Embassy and many churches of the Living Faith or Positive Confession inspirations.

Moreover, there is a unique aspect of this typology in the Nigerian Pentecostalism, which is heavily dependent on Aladura spirituality, with a theology that could be described as African shamanism. The most significance representative of this brand is the Synagogue of all Nations (Ukpong, 2012). Another typology of the Pentecostal /Charismatic churches initiated by Nigeria are the prosperity churches, following the trend of American materialism. Perhaps this is the most appealing aspect of Pentecostalism in Nigeria. These churches are scattered all over the country. The principal representatives are the Church of GodMission founded by Benson Idahosa, the Living Faith Church Worldwide, etc. Many of these churches also integrate the third wave's inspiration. Another brand of this scriptura churches is the "faith churches." These churches are developed around the theology of Faith Homes in the United States and the practice of Aladurachurches of western Nigeria. These churches forged the initial message of classical Pentecostalism with African spirituality. Their principal representative is the Redeemed Christian Church of God, the most widely spread Pentecostal church in Nigeria. Finally there is the brand of holiness movement, a continuation of the Wesleyan and Keswick an tradition of classical Pentecostalism. It represents a conservative wing of the Nigerian Pentecostalism. The only significance representative of this typology is the Deeper Life Bible Church of William Kumuyi (Ukpong, 2012).

Nigeria festivals owe their origin to the traditional religions of Nigeria. The festivals are being celebrated since the practice of the major religions in Nigeria. The various festivals of Nigeria are celebrated throughout the year and are celebrated with gaiety. These Nigeria festivals are denotative elements of Nigeria culture. Masquerades and dances play an important role in the festivals of Nigeria. Some of the eminent Nigeria festivals are the Eyo, the Shadi, Durbar, Shango and so on.

The Eyo festival is celebrated only by the Lagos people. It is also said to be the precursor of the present day Brazil carnival. All the main roadways are blocked on the Eyo day to allow the procession pass freely. The masquerade starts from Idumota to IgaIdunganran. Those who take part in this festival, pay homage to the Oba of Lagos.Eyo festival is mainly held on the last burial rites of an eminent chief, but is also held when time demands it.

The Sharo or the Shadi festival is derived from the Fulani culture. The word Sharo means flogging. The festival features unmarried men accompanied by beautiful girls to the center ring. Now a challenger starts to whip the opponent and this continues. The mob bursts out in joy and drumming and singing starts accordingly to cheer the fighters. The one wreathing in pain is considered to be the loser and coward.

The Arugungu fishing festival is the annual festival and is the most vibrant compared to the other festivals. The festival is celebrated in the Arugungu town of Kebbit state, one of the tourist attractions. The festival was celebrated as a tribute to Sultan Dan Mu'azu, when he visited the area in 1934. Since then it is celebrated every year around February and March. In this festival local people, armed with fishnets get in the water. They are then accompanied by drummers who with loud beating of their drums drive the fishes to the shallow waters. Canoe racing, fishing bare handedly, diving competitions are also a part of this festival (MYW, 2012).(see appendix for photos).

The Antilogwu dance is a remarkable art form. The dance is done with the help of foot stomping steps. Great training is needed to perform this dance and is performed in Igbos in the Anambra state. The Osun festival is celebrated in the Yorubaland and mainly worships Sango, god of thunder. Then the Benin festival is the harvest festival and is celebrated at the end of the monsoon season, when the harvests are gathered. The Durbar festival showcases the horsemanship of the people. Durbar means military parade. The Emir used to invite the nationals to exhibit their horsemanship and valor. Since then it has become a respectable festival. Today the Katsina Durbar is the most remarkable and glorious (MYW, 2012). (see appendix for photos).

The Nigeria festivals have become the tradition of Nigeria, worth seeing. Besides, there are several other local festivals celebrated with gaiety and fun

4. Methodology and Data

The study span 2000 to 2011 and it corresponds with the period which the government of Nigeria sensed the need to diversify its revenue base by instituting a new set of reforms in the tourism industry which led to the creation of the Nigeria Tourism Master Plan and thereafter. Also, the short period covered in the study is due to the unavailability of data. Data for this study were from secondary sources. The secondary sources mostly involved the materials gotten from textbooks, journals, government publications, magazines, newspapers and websites. It also involved extension review of literatures especially those ones relevant to the study. The technique of content analysis was used to analyze the contents of these materials. Tables, graphs maps and photos were equally used to support the technique of content analysis. The descriptive analysis of the data was presented in table while the graphical illustration of the data was subjected to Time Series Analysis to show annual pattern of movements of both international tourist arrivals and tourism receipts. Pearson Moment Product Correlation was applied to examine the relationship between the annual tourist arrivals and tourism receipts over the years 


\section{Analysis and Discussion}

5.1 Impact of Religious Tourism in Nigeria

5.1.1 Social Dimension

Umeije (2009) observed that the Christian fold appears to be taking the lead in contributing to tourism development in Nigeria, thanks to the upsurge of evangelical activities in the Pentecostal fold. The many Christian crusades, seminars and festivals that are held in every nook and cranny of Nigeria have become an avenue for the development of tourism, especially with the crowd that normally throngs these venues.Among the many mega churches in Nigeria, the Synagogue Church of All Nation (SCOAN) has contributed immensely to the tourism profile of Nigeria, with the influx of several heads of government from various African government to seek spiritual restoration and advise from the leader of the church.

The list of the numerous high profile visitors include King GodwillZwelithini of the Zulus, who came calling all the way from South Africa in 2007, with his daughter Princess SibusileZulu, who was suffering from partial epilepsy; in 2006, King Moloto Solomon of the Limpopo Kingdom, South Africa was in Synagogue to seek good tidings for his kingdom; In 1999,Frederick Chiluba, former president of Zambia visited Joshua in his church to seek solution to an undisclosed ailment; President Omar Bongo of Gabon had also been at the Synagogue; Professor PasalLissouba, one time president of Congo Brazzaville had been at the synagogue. Other high profile personality, include Justice Ralph Beisner from New York, South African Rugby player,JacobWesthurzen; Prince Yormie Johnson, Liberia former warlord and a senator and the new president of Ghana, John Atta Mills, who had to hold his thanksgiving service at the Synagogue church in Nigeria, in company with his vice president, John Mahama. Mahama was said to have confessed at the thanksgiving that what he saw was marvelous thus: "I have been inspired in terms of how you must consolidate the spiritual in order to achieve success in the physical"(Umejei, 2009). But beyond synagogue is a list of various Christian crusades, festivals and seminars that have contributed in no small way in positioning Nigeria as the preferred destination for religious tourism, hence giving fillip to tourism development in the country.

Living Faith Chapel, aka Winners Chapel through its annual festival, tagged Shiloh brought Nigerians from home and abroad and foreigners alike, to Otta, Ogun state headquarters of the church to seek the face of God and divine embellishments for their lives. Though, statistics of participants may be a snag but it is put at hundreds of thousand, with many high profile preachers of the gospel coming from all over the world to add verve to the event.

The Redeemed Christian Church of God (RCCG), one of the leading Pentecostal churches in Nigeria has contributed to the phenomenal growth of religious tourism through its monthly Holy "Ghost" service and yearly "Holy Ghost Congress". The number of people, both Nigerians, and foreigners that throng these festivals is said to be in excess of five hundred thousand, a boost for tourism. House on the Rock, another Pentecostal group hold its yearly festival tagged "The Experience" in Lagos, with high profile international gospel artistes in attendance, thus boasting the confidence of foreigners that Nigeria is not a haven for kidnapping and scam as it is being bandied in foreign media. The Deeper Life Bible Church (DLBC) also holds yearly Christian festival tagged "Retreat", which is also known to attract Nigerians from home and abroad, including foreigners who throng the venue of the retreat seeking one form of spiritual restoration or the other. However, Islam also accounts for many of the festivals that have helped in no small measure in developing religious tourism in Nigeria. OJude Oba, a festival held by the Ijebu Ode people of Ogun state in the South West of Nigeria has garnered international reputation, with various corporate endorsements. The festival, with roots in Islam takes place on the third day of Id -El Kabir but it is celebrated by all the natives, both Christian and Muslims. OJude Oba according to history has been celebrated for over hundred years. It commenced when the first converted Muslims thought it fit to visit their king, the Awujale, thank and felicitate with him for cooperating with them in allowing them practice their religion. The festival takes off with prayers by the chief Imam of Ijebu Ode. The history of durbar festival is said to date back to hundreds of years ago, when it was fashionable in the northern Nigeria to use horse in warfare. But in recent times, Durbar has been staged to honour visiting heads of states and very important dignitaries. Some of the popular Durbars are those of Kano and Katsina states (Umejei, 2009).

In traditional religion, the numerous festivals held by adherents have added to make religious tourism a beautiful bride that may become a platform for the explosion of tourism in Nigeria. The Osun Osogbo festival has garnered huge international following with faithful coming from various part of the world to pay obeisance to their god. The Osun river goddess is believed to hold the power to wealth and fertility, which many have found potent, hence the euphoria it has garnered among faithful. The OsunOsogbo festival is regarded as one of the prime cultural fiesta that most foreigners keep a tab on.

The Argungu Fishing festival is no doubt one of Nigeria's greatest cultural festivals, attracting over one million participants and having held since 1934. It has become a focal platform for the marketing and projection of Nigeria. 
Argungu fishing festival has also garnered enormous corporate endorsement that has positioned it as a flagship of cultural heritage in Nigeria (Umejei, 2009).

In the Niger Delta, the UdjuIwhurie Festival, popularly known as Agbasa Juju Festival is a colourful display of heritage celebrated by the Agbarha People of Warri, in Delta state. The festival has roots in Iwhurie, the god of war, reputed for its war prowess. It has been celebrated since time immemorial, with a display of machetes and regalia. The razzmatazz and display of valour by the locals make Agbasa juju festival a festival to watch. The Iriji Festival, celebrated by the Igbo people of Nigeria to certify the new yam for consumption has become a cultural heritage that has garnered international reputation, that even foreigners participate and corporate organizations struggle to endorse, in a bid to identify with the pride of the Igbos.

\subsubsection{Economic Dimension}

\section{Figure 1: Tourist Inflows to Nigeria 2000 -2011}

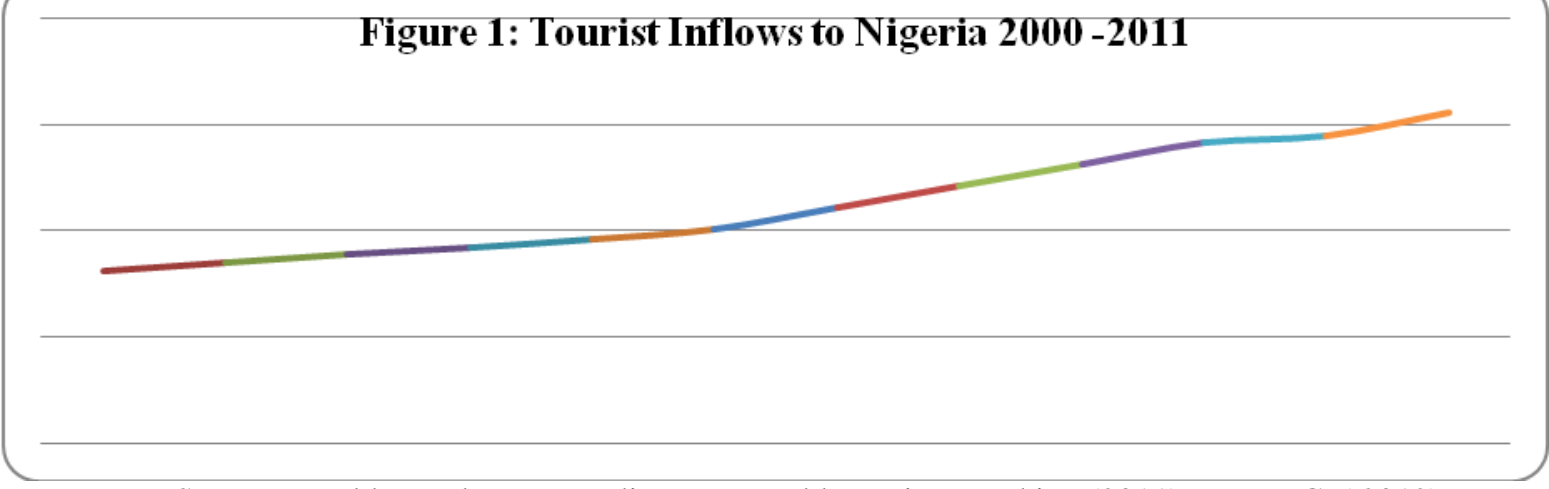

Source: World Development Indicators, World Tourism Ranking (2011), W.T.T.C. ( 2012).

Religious tourism comprises many facets of the travel industry including pilgrimages, missionary travel leisure (fellowship) vacations, faith-based cruising, crusades, conventions and rallies, retreats, festivals, monastery visits and guest-stays and faith-based camps. Religious tourism is a major factor boosting inbound flow to Nigeria. Tourist arrivals in Nigeria in 2000 recorded 813,000 , it rose to 850,000 in 2001. Within a span of three years, it climbed up to 962,000 in 2004 . The figure shot to $1,010,000$ in 2005 , showing an increase of 250000 . This also reflected in the tourism receipts. The average for the year 2000 to 2004 was 887200. The 2007 figure jumped to 1,212,000. By then, the springing up of different Pentecostal Churches across the country and the various conventions being held annually and quarterly by these churches have virtually increased. The 2011 figure was given as 1,560,000. Figure 1plots the tourist arrivals to Nigeria from 2000 until 2011. By looking at the figure,one can identify that for the most part of the time frame, the arrival of tourists is in increasingmanner and peaked at 2011 with a figure of 1,560,000 as earlier stated. The immigration record on arrivals into Lagos for the past two years through the Muritala Muhammad International Airport indicates that the

Synagogue Church of All Nations had the highest arrivals of visitors into Lagos (Jacobson, 201).

The rapid growth of religious tourism led to a growth of household incomes and government revenues directly and indirectly by means of multiplier effects. The inflow of foreign exchange into the country at this period is very high and a lot of employment is generated for the inhabitants of the area: new hotels are been built which provides employment and residential quarters are also been erected by private individuals who wants to take advantage of the growing development in the axis. The economic activities that takes place during this period is very enormous boosting the economic growth of not only the inhabitants living in the axis but also increasing the economic growth of other sectors of the economy that are direct or indirectly involved in these conventions. As a result, the development of religious tourism can generally be considered a positive contribution to the tourism sector.

This is further buttressed by the Nigerian Tourism Development Corporation (NTDC) director general Otunba Segun Runs ewe. According to him, Shiloh 2007, a gathering by the Winners Chapel, one of the evangelical churches attracted 4.5 million people for its annual congress at Otta, near Lagos in Nigeria's southwest. Shiloh 2007 attracted delegates from 35 countries 12 African and 23 non-African countries who spent eight days. Foreign delegates spent just $\$ 1.5$ million, while the Nigerian delegates spent about $\$ 630$ million during the course of the eight-day affair (UKO, 2008). However, the NTDC director general also said that, the "Holy Ghost Congress" in 2007 at Ibafon, near Lagos, of the Redeemed Christian Church of God [RCCG] attracted over 3 million people from 34 countries--14 African and 20 non-African countries, spending over $\$ 10$ million on accommodation and feeding in 
seven days by foreign delegates and about N22 billion (approximately \$200 million) by the domestic delegates on accommodation, transportation, food, souvenirs, etc., (UKO, 2008). Still, according to the report, big evangelical churches attracted over 15 million people to their retreat grounds generating N90 billion (approximately $\$ 890$ million] during the seven-day holiday period in 2007 (UKO, 2008).

Table 1 reveals that receipt from the tourism sector has tremendously improved from $\$ 186,000,000$ in 2000 to $\$ 738,000,000$ in 2011, a growth rate of 24.7 percent annually. From 2005 to 2011, the average tourism receipt for Nigeria was $\$ 558,714,285.7$. As a percentage of total export of Nigeria, tourism receipts showed performance of $1.09 \%$ and $1.36 \%$, for the year 2008 and 2009 with a slight decline to $0.96 \%$ in 2010. Figure 2(see appendix) plots the tourism receipts of Nigeria from 2000 to 2011.The curve shows an upward trend. A decrease in receipts was registered, as reflected by the fall from $\$ 256,000,000$ in 2002 to $\$ 58,000,000$ in 2003 , a decline of $77.3 \%$. The tourism receipts further declined in 2004 by $15.5 \%$. However, 1,010,000million tourists who traveled to Nigeria in 2005 generated about $\$ 139,000,000$, an increase over the 2004 receipt of $\$ 49,000,000$ (an increase of $\$ 90000000$, about $183.7 \%$ ) from 962,000 million tourists. Thereafter, tourism receipt grew phenomenally from $\$ 209,000,000$ in 2006 to $\$ 738,000,000$ in 2011 , with an average annual growth rate of $42.2 \%$. It peaked in 2008 at $\$ 959,000,000$. The correlation coefficient of 0.86 shows a positively strong relationship between tourist arrivals and tourism receipts in Nigeria. It was highly correlated $(0.86)$ at 0.01 level of significant. The degrees to which both variables are linearly associated are shown in Table 5 (see appendix). Table 6 depicts the descriptive table which displays the sample size, mean, standard deviation, and standard error for both variables while the precise frequencies for each variable are shown in frequency Tables 7 and 8 (see appendix).

Religious tourism as seen drives travel and tourism in Nigeria. As depicted in Table 1, the direct contribution of travel and tourism to GDP in 2011 was NGN598.6bn (1.6\% of GDP). That is, GDP generated by industries that deal directly with tourists, including hotels, travel agents, airlines and other passenger transport services, as well as the activities of restaurant and leisure industries that deal directly with tourists. As the table demonstrates, tourism accounted for $1.2 \%$ of the nation's gross domestic product (GDP) in 2006. From 2009 to 2011 the contribution of travel and tourism to GDP of Nigeria averaged NGN583.6 ( i.e,1.6\% on the average). It reflects tourism's paltry contribution to its national wealth. This is forecasted to rise by $11.0 \%$ to NGN664.6bn in 2012 and expected to grow by $6.3 \%$ per annum to NGN1, 223.8bn (1.8\% of GDP) by 2022 (WTTC, 2012).

Concerning employment, travel and tourism in Nigeria has been steadily creating direct jobs from 2006 to 2010 and peaking at 2008 with $1,039,000$ jobs about $1.8 \%$ of employment in the economy. It generated 838,500 jobs directly in 2011 (1.4\% of total employment) and this is forecasted to growby $7.0 \%$ in 2012 to 897,500 (1.4\% of total employment).By 2022, Travel \& Tourism is expected to account for 1,289,000 jobs directly, an increase of $3.7 \%$ per annum over the next ten years (WTTC, 2012).

Religious tourism in Nigeria is of course not free from negative impacts, every year during festivals prices of goods and services goes up. Festive seasons present opportunities for sellers to make increased profits, as people do a lot of shopping around the period. The price increase is not limited to food items; but includes clothes, shoes and varying gift items, among other necessities. Also, transport fares and hotel and restaurant charges. This increase comes when transporters increase the fares to transport trader's goods to the market. Transporters sometimes blame it on fuel scarcity.Higher prices during festivals creates fresh problems for the government, which has been struggling over the years to contain inflation. In the year 2000, the inflation rate was $6.9 \%$. It increased in 2001 to $18.9 \%$, then started falling again, and it reduced sharply in 2007 to $5.9 \%$ and then started to increase again reaching $11.5 \%$ by 2008 and $11.6 \%$ in 2009 (see Table 2 in appendix). The country's Composite Consumer Price Index (CPI), which measures inflation, dropped slightly by 1.9 per cent to 10.3 per cent in December 2011 compared to 10.5 per cent in the previous month.Average monthly food prices also rose by 2.2 per cent in December as against 0.3 per cent in the previous month (James, 2012). The price hike in food items was linked to the festive period.Generally, average headline inflation in 2011 was put at 10.9 per cent compared to 13.8 per cent in 2010 . The fall in inflation rate followed monetary policy tightening and the easing of food prices. Inflation is projected to ease to $10.1 \%$ in 2012 and $8.4 \%$ in 2013 (ADB, 2012). The government is expected to reach its target of getting inflation under $10 \%$ in 2013 (ADB, 2012).

Table 2 in the appendix presents the statistical records for Nigeria's economic performance during the study period in respect of GDP per capita, life expectancy rate at birth, literacy rate, population of Nigerians below poverty line, and unemployment rate in the country, external debt.

Despite the impressive GDP per capita over the last 12 years, unemployment and the Population below Poverty Line has worsened since 2003. The Population below Poverty Line figures for 2010 and 2011 for Nigeria were $60.9 \%$ and $62.8 \%$ compared to $4.90 \%$ in 2009 . The unemployment rate declined from $70 \%$ in 2009 to 21.1 in 2010 and 23.9 in 2011 corroborating the job creation by travel and tourism. Between 2000 and 2011, life expectancy at birth in Nigeria increased by 0.66 years or at a rate of 0.06 years annually and literacy rate increased by $16.6 \%$ (at a rate of 
$1.4 \%$ annually). Nigeria's GNI per capita increased from US\$ 970 in 2000 to US\$2,069 in 2011 averaging US\$ 1327.3 and increasing at a rate of 9.4\% annually between 2000 and 2011. However, between 2004 and 2010, Nigeria's economy grew strongly at an average annual growth rate in excess of $6.6 \%$, making the country the 5th fastest growing economy in the World in 2010 at 7.87\% real growth rate (BGL, 2011).

On the other hand, the country's external debt has been growing in spite of the efforts being made by the Government to manage and minimize its crushing effects on the nation's economy. Between 2000 and 2004, Nigeria'sexternal indebtedness rose from US\$29million to over US\$31million. Externaldebt as a percentage of the GDP was 66\% in 2000 and $75.6 \%$ in 2004 (Ezeabasili, Isu and Mojekwu, 2011). The external debt went up to US\$ 56,300 in 2011 (about $81.2 \%$ increase). For 2012, Nigeria external debt is projected at $\$ 9,021.53$ billion; 2013 ( $\$ 12,165.10$ billion); 2014 ( $\$ 14,585$ billion) and 2015 ( $\$ 16,765$ billion) (Ovuakporiev, 2012). The above represents the paradox of growth in the face of poverty and inequality (BGL, 2011).

5. Policies toward Enhancing Tourism in Nigeria

The Federal Government of Nigeria in its determined efforts to develop and promote tourism into an economically viable industry had in 1991 evolved a tourism policy. The main thrust of the policy is to make Nigeria a prominent tourism destination in Africa, generate foreign exchange, encourage even development, promote tourism-based rural enterprises, generate employment, accelerate rural-urban integration and foster socio-cultural unity among the various regions of the country through the promotion of domestic and international tourism. It also aims at encouraging active private sector participation in tourism development.

5.1Constraints and Hindrances to the Growth of Nigeria's Religious Tourism

Nigeria is a relative large country which occupies about 923,768 square kilometers. The vegetation of the country ranges from mangrove forest on the coast to savannah grass in the far north. The country has 36 States and the Federal Capital Territory (FCT) with 774 Local Government Areas (LGAs). But inventory of all tourist sites in their localities are not published to bring them into limelight. There are several other negative aspects affecting religious tourism in Nigeria in general. Of particularly interest is the accessibility constraint to tourist sites in Nigeria which has been identified to limit the economic potentials of these sites as catalyst of economic development. Accessibility is a major issue in the patronage of some religious tourist sites, especially, for tourist sites that are found in rural towns. For religious tourism sites located in the urban areas, the general development that come the way of the area is so much that the rate of economic development along the axis greatly improve. New hotels are built which provides employment and residential quarters are also been erected by private individuals who want to take advantage of the growing development in the axis. But for sites located in the urban areas, hotel facilities are inadequate and some of the facilities are dilapidated.

Though Nigeria has relatively advanced power, road, rail, and information and communications technology (ICT) networks that cover extensive areas of the nation's territory. But worrisome challenges persist in a number of areas, and loom the largest in the power sector. Inoperative generation capacity and lack of investment mean that the country has been able to meet only about half of its power demand. This, in turn, has resulted in an extremely unreliable supply; less visible, but also disturbing, is the water and sanitation sector's lack of development, compared to other services. Piped water coverage is only a fraction of the nation's electrification rate, and access has been declining steeply in recent years, even as the practice of open defecation continues to rise (Foster and Pushak, 2011). Moreover, water utilities appear no more efficient than the power utility. Irrigation development also remains low relative to the country's substantial potential. Last but not least, Nigeria's road networks are in relatively poor condition, testifying that assets are not being adequately maintained. The country's poor air transport safety record is reason for further concern.

In spite of all the improvement and innovation accompanying the deregulation and privatization of airline services in Nigeria however, there are some challenges still prevalent in the system. For instance, some challenges as inadequate stand for airline users, flight information and public address systems echoes, poor customer relations, flight delay, missing luggage and personal items and security issues. In addition, the air fares are high in Nigeria compared to what is obtainable in other places, but the cost of operations is also very high. The airlines cannot train enough manpower that will sustain the industry so there will be efficiency, which will eventually drive down the cost of operation (Adeniyi and Cmilt, 2011). Nigeria has 22 airports operated by the Federal Airports Authority of Nigeria (FAAN), four of which are functional international airports. It also has a state owned airport located in Akwa Ibom State ( see Table 3 in appendix).

Today many religious tourism sites in Nigeria are receiving huge influx of visitors, especially in peak periods this causes severe management difficulties as well as the general site conditions. Also, violent crimes, civil unrest, kidnapping for ransom and terrorism which are on going on a daily basis in Nigeria are detrimental to tourism. This makes organizing large events generally complex. Even though Nigeria is been visited by many tourist, some foreigners who have not visited yet depend on major news corporation who thrive on the surreal things around the 
country for their knowledge. Thus it is quite difficult for many to appreciate the size of the country and remoteness of some of the flash points from possible holiday destinations. It is quite too easy to associate a bomb blast in Madalla, Niger State to Lagos even though the former is more than a day's journey by road from the latter (BGL, 2012). The back to back negative global press coverage of the Boko Haram attacks could lead to state profiling and a contagion of even well to do states. Thus a foreigner planning a holiday to Nigeria may be put off by the travel warnings released by his/her country's Home Office without bothering to find out the remoteness of distance from the flash point and the holiday destination.

As a country with multi-religious and multi-ethnic society, Nigeria has enormous potential for economic and social development. However, intense conflicts and violence that manifested within it from its earliest time under colonial rule have made development elude the country.Nigeria is usually characterized as a deeply divided state in which major political issues are vigorously contested along the lines of complex ethnic, religious, and regional divisions (Aliyu, 1996).

According to Sampson (2012), the foremost incidence of religious violence since Nigeria's return to democracy in 1999 was triggered by an alleged violation of a traditional religious rite. Although lack of adequate statistical data has made it extremely difficult to estimate the exact number of religious conflicts in Nigeria and their resultant fatalities (Salawu, 2010:345), the general assumption is that the incidence of religious violence has grown exponentially since the return to democratic rule in 1999. Statistics on religious crises across the country however show that at least 95 per cent of them occurred in the northern part of the country (Ezeanokwasa, 2009), (see Table 5 in Appendix). In view of the perennial religious tensions between the two dominant religious groups in Nigeria, there is a sustained culture of mutual suspicion and unhealthy rivalry between them. The introduction of sections 38(1) and 10 into the Nigerian Constitution, which have guaranteed freedom of religion and prohibited the declaration of state religion respectively, has done little to attenuate the frequency of religious conflicts, as state patronage and veneration of the two dominant religious groups has helped in heightening the underlying tensions and rivalry (Sampson, 2012). Thus conflicts between Nigerian Christians and Muslims have often manifested in violent inter-religious violence. The traditional religion is not by any means insulated from religious violence (Osaghae and Suberu 2005:11).

6. Conclusion, Recommendations, Limitations and a Research Agenda for the Future

Tourism is one sector that Nigeria leaders have not really given the needed attention and development. As a fast growing aspect of tourism, religious tourism, has become the highest earner of foreign exchange for the Nigeria's tourism industry; it is also rank the second in Africa after Egypt and the highest in the black race. The springing up of different Pentecostal Churches across the country and the various conventions being held annually and quarterly by this churches have virtually increase the numbers of arrivals from overseas countries who visit the country to attend various religious programs.

Although Nigeria is yet to fully exploit this line of tourism but it has begun to recognise it. It is argued in this paper that if religious tourism is well developed and harnessed, needed infrastructure provided, an enabling environment created and good government policy implemented, can be a powerful forces for economic growth, job creation, cultural preservation and peace. As such, several challenges must be addressed. This paper suggests that:

Since the number of religious tourist both domestic and international are gradually increasing. Infrastructure around the sites needs to be improved to cope up with the increase in number of tourists. Transportation to reach the sites and accommodation needs to be upgraded. Government should make effort to purchase additional homes around these sites, especially those in the urban areas and convert them to hotels or inns. This is likely to help in expanding the tourism sector in those regions in the years to come. In general, government should further improve basic infrastructure to facilitate tourism flows around the country: it should construct or upgrade to international standards roads leading to major cities and rural areas and also should provide basic amenities such as electricity, good water, and effective communication systems in tourism destinations. Similarly, the hospitality industry needs to upgrade existing facilities to meet international standards.

Local government councils should take inventory of all tourist sites and festivals in their localities and these should be published so as to bring these tourist sites into limelight. The Nigerian Tourism Board should be made to play effective role in the advertisement and publicity of the numerous traditional festivals and rural tourism sites. Of focus should be culture, tourism and national re-orientation. These three endeavors are interrelated and yet unique in their own right. Culture is the bedrock of what Tourism is built on, while National Re-orientation is what cements them together. A nation without a culture is like one without identity. Tourism helps to promote culture and the environment and is a veritable tool for economic empowerment and social development. A re-orientated people will reflect this in their culture which in turn will affect national life and therefore engender a sustainable tourism.

Moreover, governments should ensure that a reasonable amount of money is earmarked for the development of tourism sites in their annual budget. The rehabilitation of tourist sites should be thoroughly monitored by 
government operatives so as to stall their abandonment, especially in the rural areas. In the same vein, there could be collaboration between the government and the private sector to ensure public-private participation in boosting the image of these tourist sites. The government could help to create an enabling environment and to ensure the monitoring of their sustenance while the private sector sees to their financing and management. It is believed that this participation will contribute immensely towards better accessibility to and patronage of the tourist sites and ultimately enhance their contribution towards the development of local and national economy.

Since crime, civil unrest and terrorism stunt the tourism trade, organizers and stakeholders of tourism must ensure the safety and security of tourists. As such they liaise with the Federal, State, and Local Governments in Nigeria to form a Joint Security Team for Tourism, (JSTT) comprising of the army, police, air force, navy and private security companies. They must identify the possible security hazards and the implications for tourist events and destinations. JSTT should be engaged overnight to protect the physical facilities, equipment, premises security fences and activities areas (Adora, 2010). The JSTT should apply the target-hardening security method to counter the operation of criminals and terrorists directed at tourists and tourist destinations. One of the ways of hardening the targets is bag searching for explosive and should be conducted before the search subjects enter an area of high population concentration. Another method is to place concrete barriers at sufficient distance outside buildings to prevent truck bombing. Synonymous with the above, the Joint Security Task Force for Tourism trade should deploy the Foot and Motorized Patrol System (Beat Patrol System) in low and high risk areas to guard tourist destination areas. This increases the chances of criminals being apprehended and reduces potential criminal activities (Igbo, 125).

On a final note, the Federal Government of Nigeria must adequately fund the agencies saddled with responsibilities of maintaining aviation industry. The Agencies must ensure that the safety and security of passengers and aircraft at all Nigerian airports are in line with Civil Aviation Organization (ICAO) standard. The facilities at the airports should be upgraded to world-class standard in order to enhance operational efficiency. The agencies must be thorough by examining any aircraft within and into Nigeria and certify them accordingly.

For religious harmony to be achieved in Nigeria, a neo-religious educational praxis that would generate a culture and orientation of multi-religiosity in children and youth must be establishment and sustenance of program of reorientation of the adult population. In the same vein, all religious communities must educate their clergy on the need for religious harmony and the toleration of other faiths.

The main limitation of the present study is the collection of statistics on religion and related Activities in Nigeria. There is no particular ministry or establishment that co-ordinates the activities of religious tourism. Another problem is that the different religions are so divergent in orientation that it is difficult to synchronize their datasets or encourage collaboration. These factors have made it difficult to conduct a very robust empirical research on religious tourism in Nigeria. However, the results derived from this study form an excellent basis for future work that should be undertaken in this promising area:

-Various agencies connected with the different sections of religion and related activities should take interest in the collection and publication of relevant data. Thus providing a strong basis to empirically investigate the activities of religious groups including the category which do not fall into any of the three main identities (Christianity, Islam and Traditional Religions ).

- Investigation should be carried out on the relationship between tourists and the religions andreligious contexts they visit. Why tourists travel to places of religious significance in Nigeria and how they conceive of their travels are important questions to both the study of tourism and of religion.

- research should be conducted to know whether during the stay of tourists in the destinations, their interacts with local resident produced changes in the host individuals' and host community's quality of life, value systems, attitudes, behavioural patterns and creative expressions.

References

ADB (2012). Nigeria African Economic Outlook.http://www.afdb.org/fileadmin/uploads/afdb/Documents/Publicatio ns/Nigeria\%20Full\%20PDF\%20Country\%20Note_01.pdf.

Adebola, O. I. ,Talabi, F. O., and Lamidi, I. K. (2012).RebrandingNigeria: The role of Advertising and PublicRelations at Correcting Nigeria Image. International Research Journals,3(5),424-428.

Adeniyi, O., and Cmilt, O. (2011). Airline Services in Nigeria: An Empirical Analysis. International Business Management, 5(4), 218-222.

Adora, C. U. (2010). Managing Tourism in Nigeria: The Security Option.Management Science and Engineering, $4(1), 14-25$

Alao, A. (2010). IslamicRadicalisation and Violence in Nigeria.Country Report.http://www.securityanddevelopment.org/pdf/ESRC\%20Nigeria\%20Overview.pdf.

Aliyu,S. (1996).Religious-based Violence and National Security in Nigeria: Case Studies of Kaduna State and the Taliban Activities in Borno State.A thesis presented to the Faculty of the U.S. Army Command and 
General Staff College in partial fulfillment of the requirements for the degree Master of Military Art and Science General Studies.Fort Leavenworth, Kansas.http://www.dtic.mil/cgibin/GetTRDoc?AD=ADA501810

BBC News (n.d.). Fishing Festival.http://news.bbc.co.uk/2/shared/spl/hi/picture_gallery/05/africa_fishing_festival/html/7.stm

Bella Naija (2012). Experience Nigeria: The 2011 Argungu International Fishing and Cultural Festival sponsored by Maltina.http://www.bellanaija.com/2011/04/05/experience-nigeria-the-2011-argungu-international-fishingand-cultural-festival-sponsored-by-maltina/

Blackwell, R. (2007). Motivations for Religious Tourism, Pilgrimage, Festivals and Events. In, R. Raj and N. Morpeth, Religious Tourism and Pilgrimage Festivals Management: An International Perspective, CABI Publishing, Wallingford, UK. pp. 35-47.

BGL (2011). Economic Note: The Nigeria's Paradox of Growth amidst High Poverty Incidence. http://research.bglgroupng.com/Documents/EconomicNote/ECONOMIC\%20NOTE\%20Nigeria's\%20Paradox\%20of\%20Growth\%20amidst\%20high\%20incidence\%20of\%20Poverty.pdf.

BGL (2012).Nigerian Tourism Industry: A Revolutionized Tourism Sector as a Panacea for a thriving Hospitality Business. Economic Note. www.bglgroupng.com

Bywater, M. (1994).Religious Travel in Europe.Traveland Tourism Analyst1994 (2), 39-52.

CBN Annual Reports and Statement of Account (various years).

CBN Statistical Bulletin (2006). Nigeria.,vol. 17, December.

Chron (2012).Nigeria OsunOsogbo Festival.http://www.chron.com/news/nation-world/gallery/Nigeria-OsunOsogbo-Festival-47951/photo-3364577.php

Collins-Kreiner, V. (2010).Current Jewish Pilgrimage Tourism: Modes and Models of Development, Tourism: Preliminary Communication, 58 (3), 259-270.

Egresi, I., Bayram, B., and Kara, F. (2012). Unlocking the Potential of Religious Tourism in Turkey. GeoJournal of Tourism and Geosites, 1(9), 64-80. http://gtg.webhost.uoradea.ro/PDF/GTG-12012/6_105_Istvan.pdf.

Ezeabasili, V. N., Isu, H. O., and Mojekwu, J. N. (2011).Nigeria's ExternalDebt and EconomicGrowth: An Error Correction Approach, International Journal of Business and Management, 6(5), 156-169.

Ezeanokwasa, J. O. (2009). Islamic banking, CBN, secularity and unity of Nigeria.Vanguard online, 29 August 2009. Available from: <http://odili.net/news/source/2009/aug/29/307.html>.

Foreign and Commonwealth Office (2012).Country Information.http://www.fco.gov.uk/en/travel-and-livingabroad/travel-advice-by-country/country-profile/sub-saharan-africa/nigeria/

Foster,V. and Pushak, N. (2011). Nigeria's Infrastructure: A Continental Perspective. Africa Infrastructural Country Diagnostic (AICD), Country Report.

Gaiya, M.A. B. (2002). The Pentecostal Revolution in Nigeria. An Occasional Paper of the Centre of African Studies, University of Copenhagen, July 4.

Graburn, N. H. (1977). Tourism: The Sacred Journey, In, V.L. Smith (ed.), Hosts and Guests: The Anthropology of Tourism.University of Pennsylvania Press,Philadelphia, Penn. pp. 21-36.

Grainsofafrica (n.d.) .TheEkpe Masquerade. http://www.grainsofafrica.com/catalog/african-

Igbo, M.U.E. (1999). Introduction to Criminology, Afro Orbis publishing Co Ltd, Nsukka.

Jacobson, A. (2012). Religious Tourism: Fastest Growing Aspect of Holiday Industry. Austin Jacobson. Tourism. http://austinjacobsontourism.blogspot.fr/2011/09/religiou-tourism.html.

James, E. (2012). NBS: Nigeria Lost N207bn to Strike. This Day Live.http://www.thisdaylive.com/articles/nbsnigeria-lost-n207bn-to strike/107467/.

Josan, I. (2009). Pilgrimage- A Rudimentary Form of Modern Tourism.GeoJournalof Tourism and Geosites, 2 (4), $160-168$.

LEARN NC (n.d.). Map of linguistic groups in Nigeria.http://www.learnnc.org/lp/multimedia/8819

Map of Your World (MYW) (2012). Nigeria Festivals.http://www.mapsofworld.com/nigeria/culture/festivals.html.

Milne, S., and Ateljevic, I. (2001). Tourism, Economic Development and the Global-Local Nexus: Theory Embracing Complexity, Tourism Geographies, 3(4), 369-393.

Neto, F. (2002). Sustainable Tourism, Environmental Protection and Natural Resource Management: Paradise on Earth?,Paper submitted to the International Colloquium on New Partnership for Africa's Development (2004). NEPAD Tourism Action Plan, Report presented at 41st WTO/CAF Meeting, Luanda Angola.

Nigeria Economic Fact Sheet (2012). Development Figures .United States Embassy in Nigeria.http://photos.state.gov/libraries/nigeria/231771/Public/December-EconomicFactSheet.pdf; 
Nigerian Institute of Social and Economic Research (NISER) (2008).National Manpower Series.Compiled in Abuja, 2000-2008.

National Bureau of Statistics (2005). Nigeria.

Nolan, M., and Nolan, S. (1992). Religious Sites as Tourism Attractions in Europe.Annals of Tourism Research,19(1), 68-78.

Osaghae E. E., and Suberu, R. T. (2005).A History of Identities, Violence, and Stability. In: Nigeria Centre for Research on Inequality, Human Security and Ethnicity (CRISE), Working paper No. 6.

Ovuakporiev, E. (2012). Nigeria's Debt Profile Rises, to Borrow \$25bn by 2015. Vanguard Newspaper.http://www.vanguardngr.com/2012/10/nigeria-debt-profile-rises-to-borrow-25bn-by-2015/.

Panoramio (n.d.). The Synagogue Church of All Nations, Nigeria. http://www.panoramio.com/photo/17843920

Pusztai, B. (2004). Religious Tourists: Constructing Authentic Experiences in Late Modern Hungarian Catholicism. Ph.D. dissertation, University of Jyvaskyla/Jyvaskyla Studies in Humanities.

Raj, R. (2008).The Application of Destination Management Model for Religious Festivals, Tourism Today.The Journal of the College of Tourism and Hotel Management, 8(1), 118-128.

Rinschede, G. (1992). Forms of Religious Tourism.Annals of Tourism Research 19, 51-67.

Salawu, B. (2010). Ethno-religious Conflicts in Nigeria: Causal Analysis and Proposals for new Management strategies. European Journal of Social Sciences, 13 (3), pp. 345-353.

Sampson, I.T. (2012). Religious Violence in Nigeria: Causal Diagnoses and Strategic Recommendations to the State and Religious Communities.African Journals Online (AJOL).http://www.ajol.info/index.php/ajcr/article/viewFile/78703/69042

Sharpley, R., and Sundaram, P. (2005).Tourism: A Sacred Journey, the case of Ashram Tourism India.International Journal of Tourism Research, 7(1), 161-171.

Shinde, K., A. (2007). Case Study 6: Visiting Sacred Sites in India: Religious Tourism or Pilgrimage, In, R. Raj and N. Morpeth, Religious Tourism and Pilgrimage Festivals.Management: An International Perspective, pp. 184-197. Wallingford, UK: CABI Publishing.

Smith, V. (1992).The Quest in Guest.Annals of Tourism Research, 19, 1-17.

Swarbrooke, J. (1999). Sustainable Tourism Management, New York: CABI Publishing, UNWTO (2011), Tourism Highlights: International Tourism, http://mkt.unwto.org/sites/all/files/docpdf/unwtohighlights11enhr.pdf.

This Day Live (2011). Nigeria's External Debt hits \$ 5.63bn. http://www.thisdaylive.com/articles/nigerias-externaldebt-hits-5-63bn/104101/

Timothy, D., and Olsen, D. (eds) (2006). Tourism, Religionand and Religious Journeys .

Routledge: London.

Tomasi, L. (2002). Homo Viator: from Pilgrimage to Religious Tourism via the Journey, in Swatos, W.H. Jr and Tomasi, L. (eds) From Medieval Pilgrimage to Religious Tourism: the Social and Cultural Economics of Piety. Praeger, Westport, Connecticut, pp, 1-24.

Trading Economics (2012).Labour Participation rate; Total (\% of Total Population Ages +15 ) in Nigeria.http://www.tradingeconomics.com/nigeria/labor-participation-rate-total-percent-of-totalpopulation-ages-15-plus--wb-data.html Tyrakowski, K. (1994). Pilgrims to the MexicanHighlands. In Pilgrimage in the Old and NewWorld, Bhardwaj S, Rinschede G, Sievers A (eds).Dietrich Reimer Verlag: Berlin; 193-246.

Uko, I. (2008).Mega Churches Stir Tourism in Nigeria.Nigeria (eTN). http://www.eturbonews.com/752/mega-churches-stir-tourism-nigeria

Ukpong, D. P. (2012). The Presence and Impact of Pentecostalism in Nigeria.http://www.glopent.net/Members/frdo na/presence-and-impact-of-pentecostalism-in-nigeria.pdf.

Umejei, E. (2009). Religious Tourism: Nigeria's Fastest Growing Tourism Sector. Emekaumejei Weblog. http://emekaumejei.wordpress.com/2009/03/02/religious-tourism nigeria\%E2\%80\%99s-fastestgrowing-tourism-sector/.

Vukonic, B. (1998). Religious Tourism: Economic Value or an Empty box? Zagreb International Review of Economics and Business, 1(1), 83-94.

Wikipedia (2012a), Nigeria. http://en.wikipedia.org/wiki/Nigeria.

Wikipedia (2012b).Islam in Nigeria.http://en.wikipedia.org/wiki/Islam_in_Nigeria

Wikipedia (2012c).Nigeria. http://en.wikipedia.org/wiki/File:AbujaNationalMosque.jpg

Wikipedia (2012d).Religion in Nigeria. http://en.wikipedia.org/wiki/Religion_in_Nigeria

Wikipedia (2012e). Nigeria. http://en.wikipedia.org/wiki/Nigeria

Wikipedia (2012f). Nigeria. http://en.wikipedia.org/wiki/Nigeria 
Wikipedia (2012g). Nigeria. http://en.wikipedia.org/wiki/Nigeria

Wikipedia (2012h).Yoruba Religion.http://en.wikipedia.org/wiki/Nigeria

World Bank Economic Statistics(n.d.). Nigeria. http://www.indexmundi.com/nigeria

World Development Indicators(2011). Nigeria. http://data.worldbank.org/indicator/ST.INT.ARVL

World Tourism Ranking (2011).International Tourist Arrivals to Nigeria. Wikipedia: http://en.wikipedia.org/wiki/World_Tourism_rankings.

World Trade \& Tourism Council (2012).Travel and Tourism: Economic Impact, Nigeria. http://www.wttc.org/site_media/uploads/downloads/nigeria2012.pdf.

\section{Appendix}

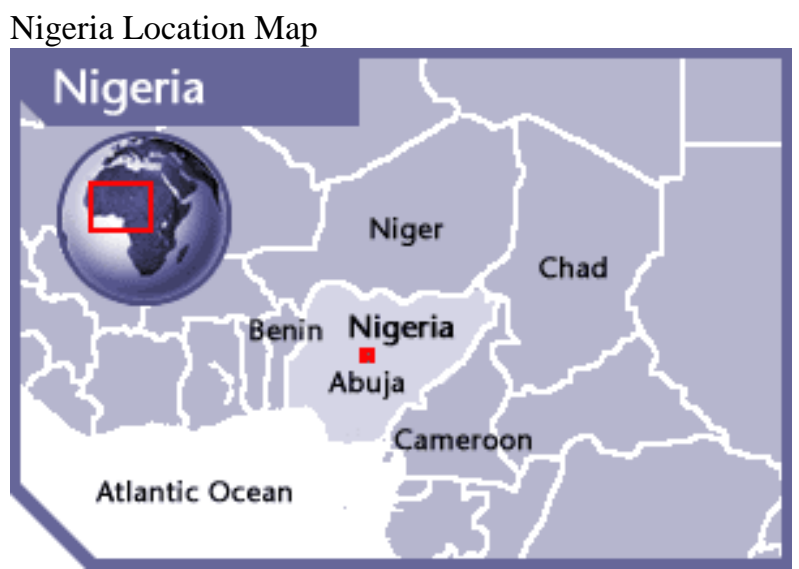

Area: 923,768 sq km (356,700 sq miles);Population: 160 million (World Bank, 2012); Capital City: Abuja; Other Major Cities: Lagos, Ibadan, Kano and at least 7 other cities with a population of over 1 million; People: Hausa/Fulani, Yoruba, Igbo, Ijaw and some 250 ethno-linguistic groups; Language(s): English (official) but Hausa, Yoruba, Igbo are also used in the National Assembly; Religion(s): Muslim, Christian and traditional Source: Foreign and Commonwealth Office (2012).

Map ofNigeria exhibiting its 36 states and the federal capital territory and population

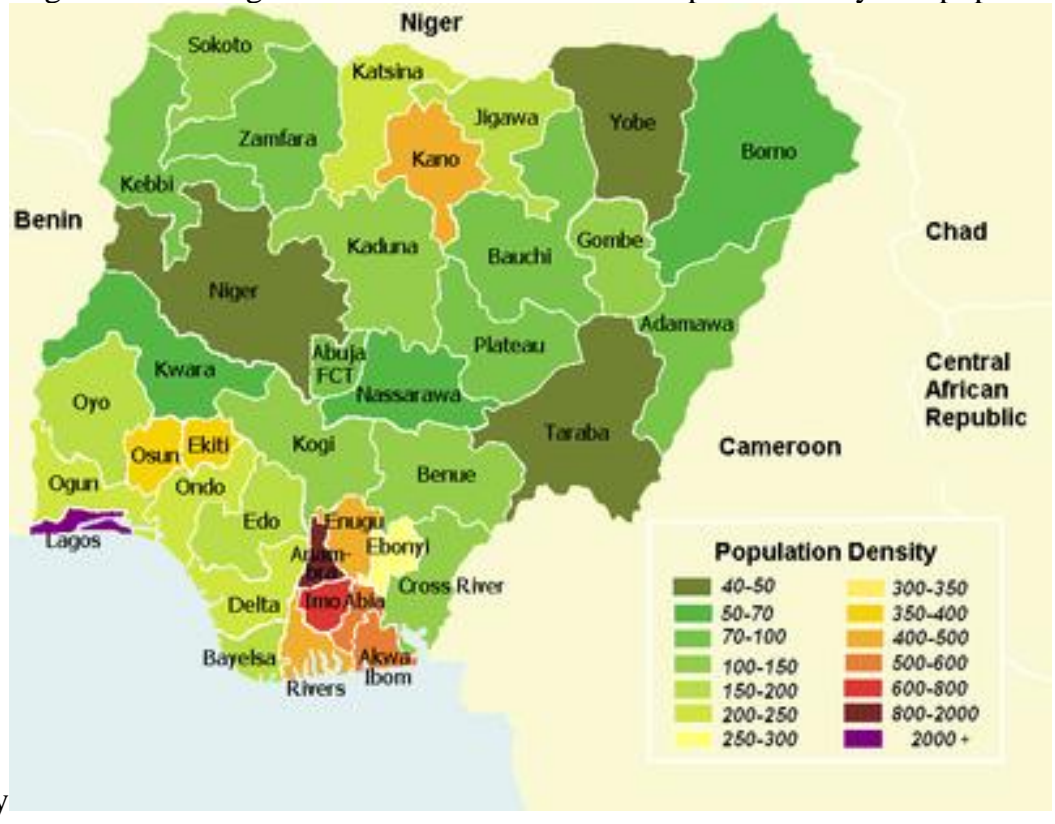

density

Source: Wikipedia (2012a). 
Religion and Ethnic Map of Nigeria

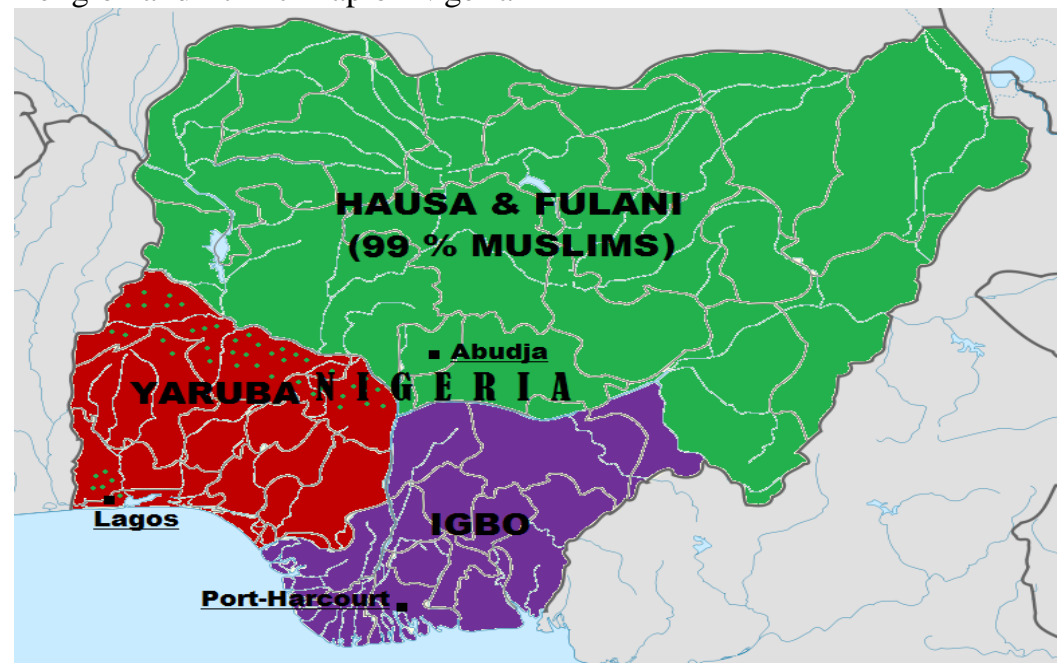

Source: Wikipedia (2012b).

Map of linguistic groups in Nigeria

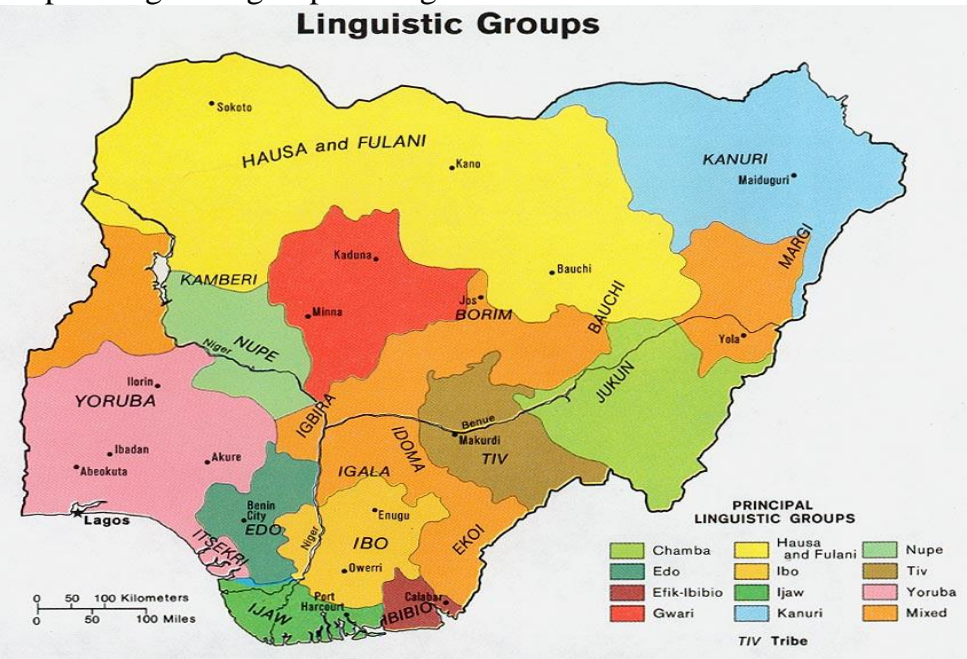

Source: LEARN NC (n.d.).

\section{Religion}

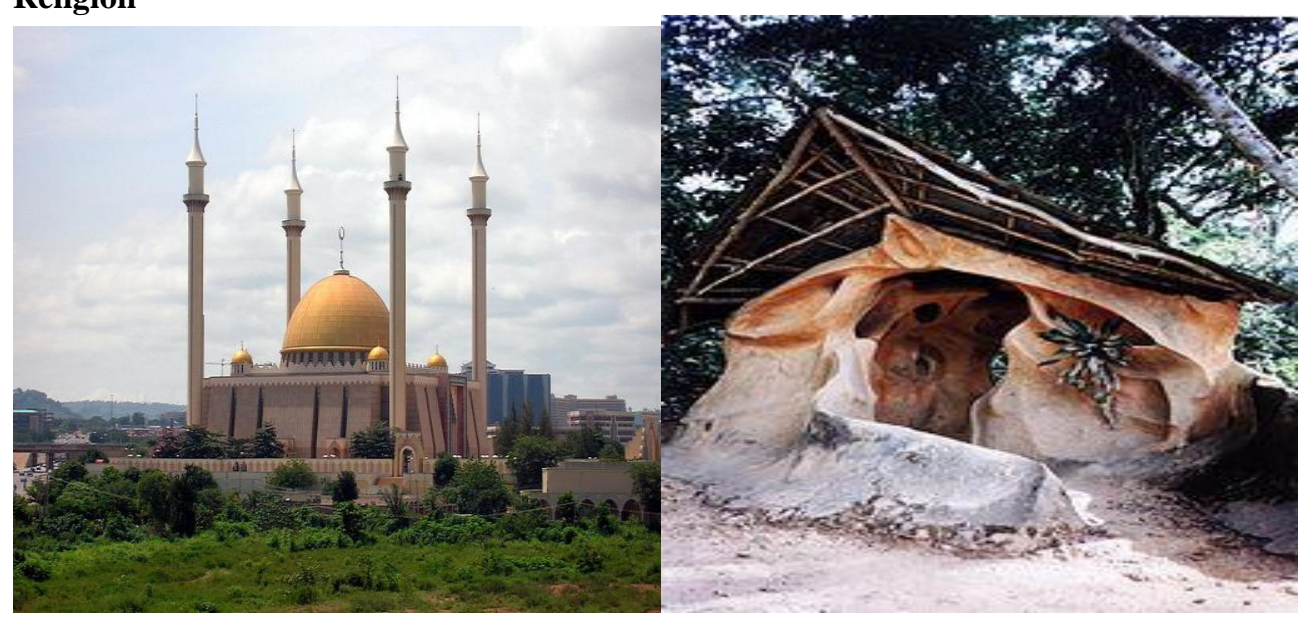


Source: Wikipedia (2012c, 2012d).

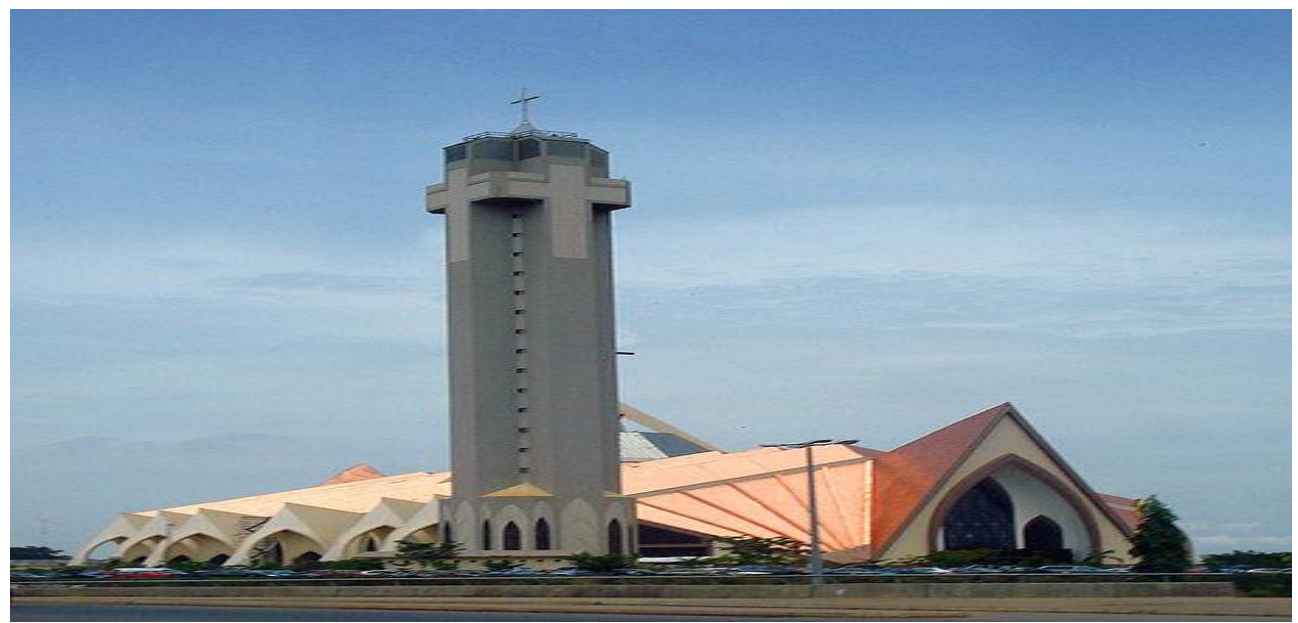

CatedralNacionalem Abuja, Nigéria

Source: Wikipedia (2012e).

Nigeria religion comprises a number of religions, mainly Christianity, Islam and the traditional religion of Nigeria.

\section{Ethno-linguistic groups in Nigeria}

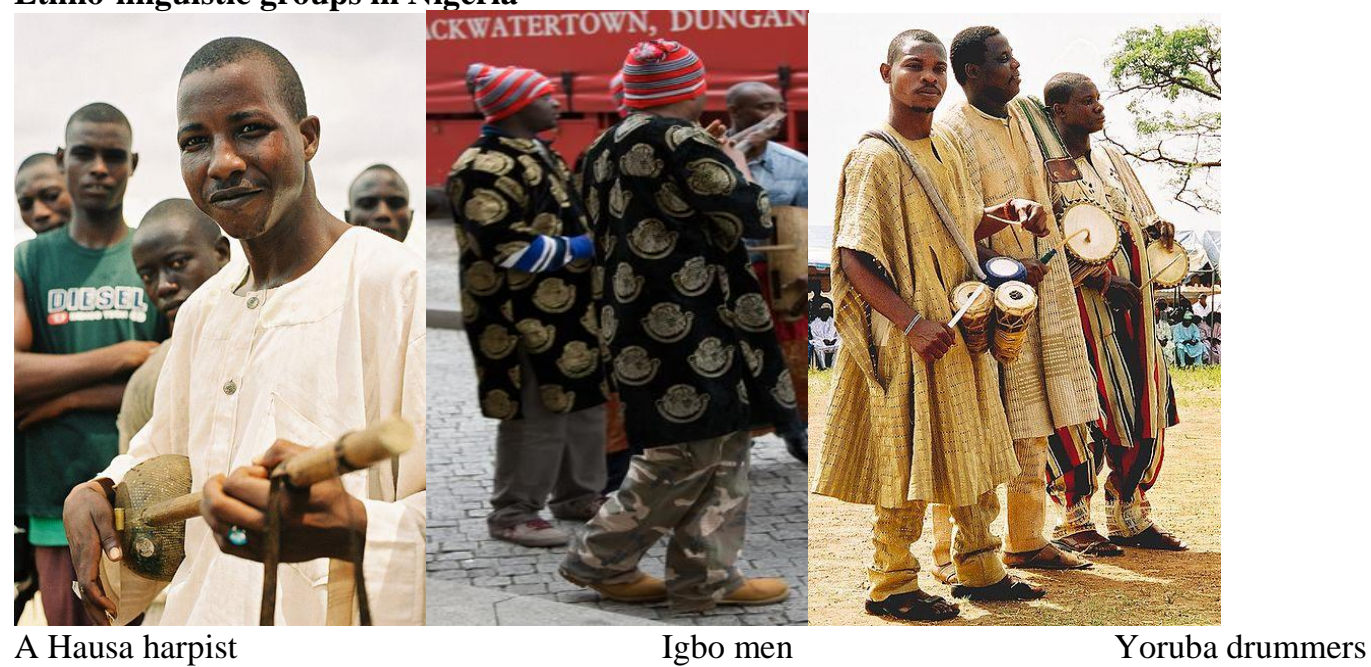

Nigeria has more than 250 ethnic groups, with varying languages and customs, creating a country of rich ethnic diversity. The largest ethnic groups are the Fulani/Hausa, Yoruba, Igbo.

Source: Wikipedia (2012f).

The Synagogue Church of All Nations, Nigeria

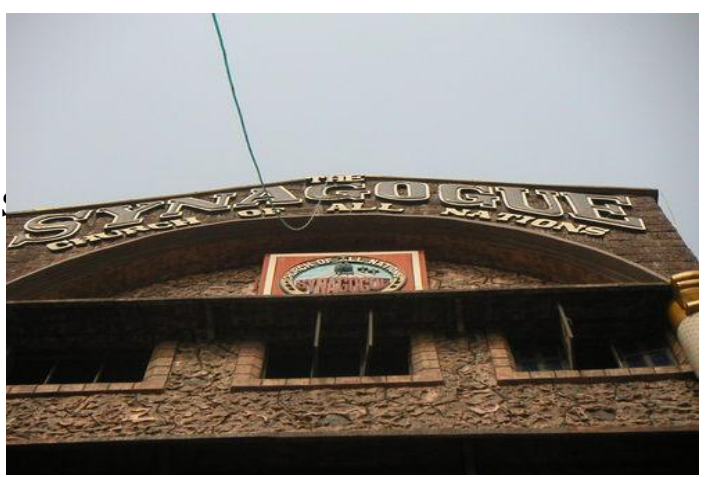




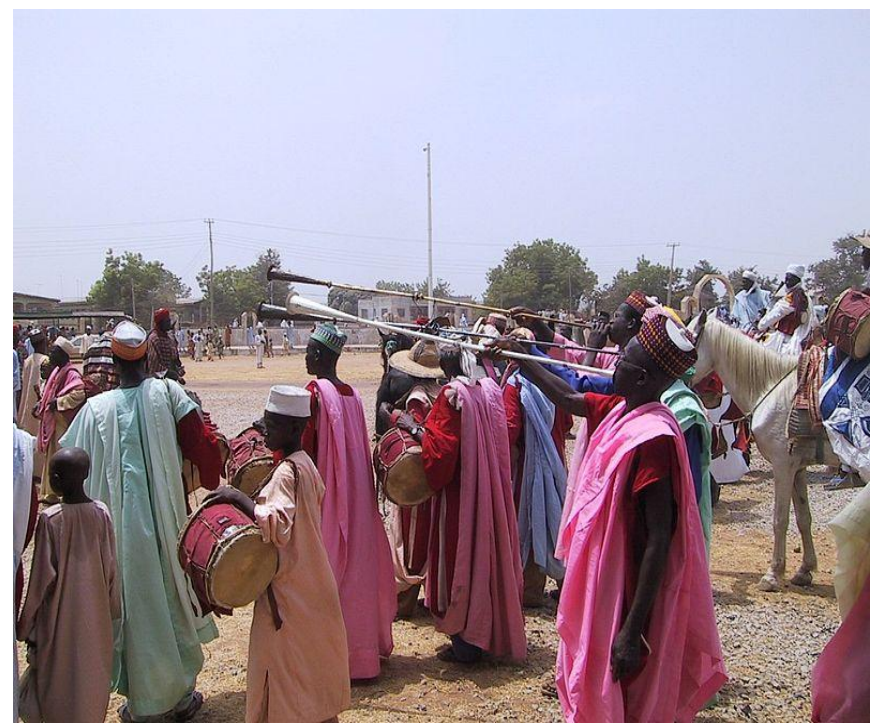

Bida Emirate durbar festival Source: Wikipedia (2012g).

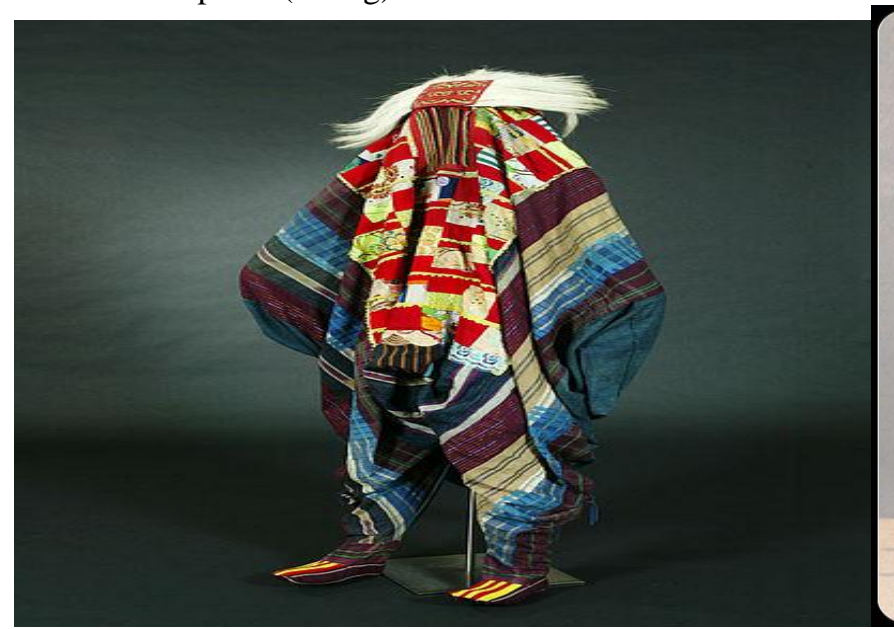

A Egungun masquerade dance garment Source: Wikipedia (2012h).

Source:Grainsofafrica (n.d.)

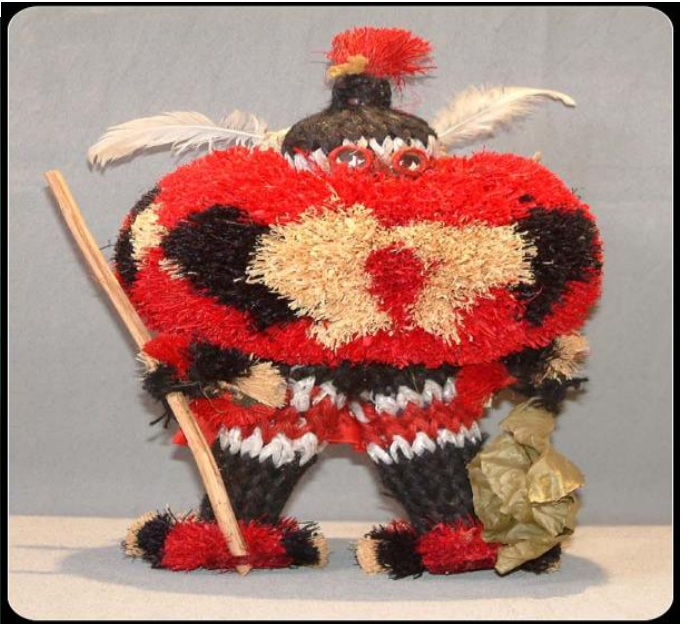

TheEkpe Masquerade originates from the Efiks in Cross River State of Nigeria

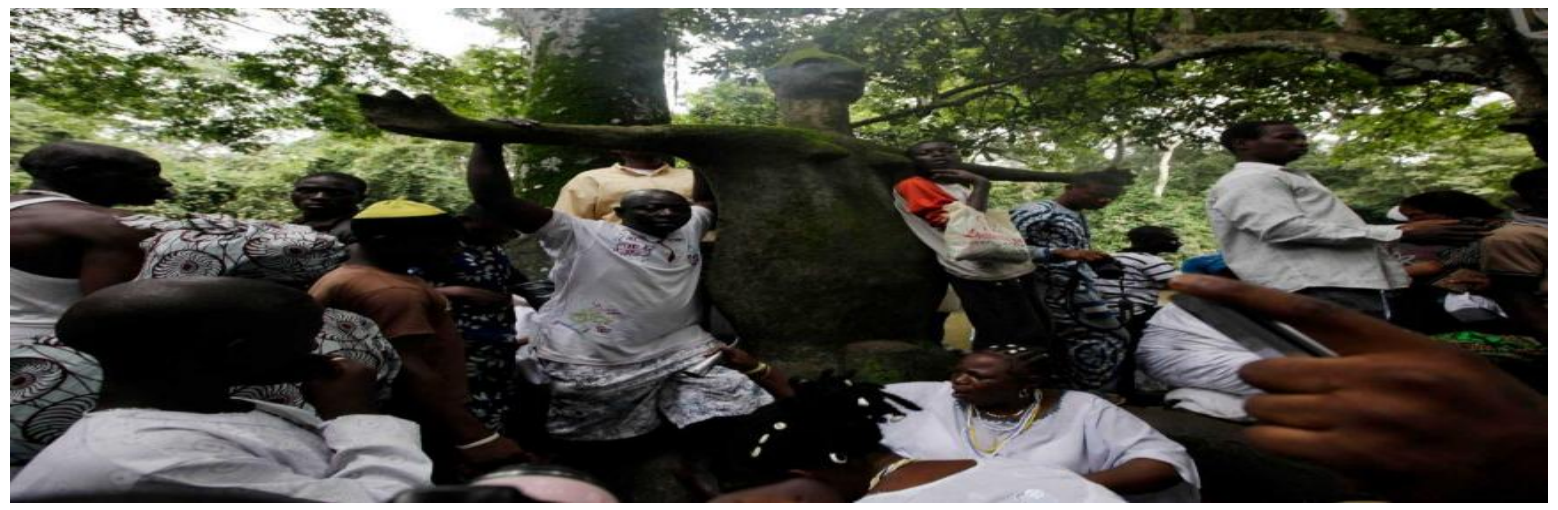

The OsunOsogbo Festival of Nigeria is based on the cultural and religious practices of the Osogbo people of Nigeria. This festival is annually celebrated by the yoruba-speaking people of Nigeria and internationally visited in honor of the Osun goddess.

Source: Chron (2012). 


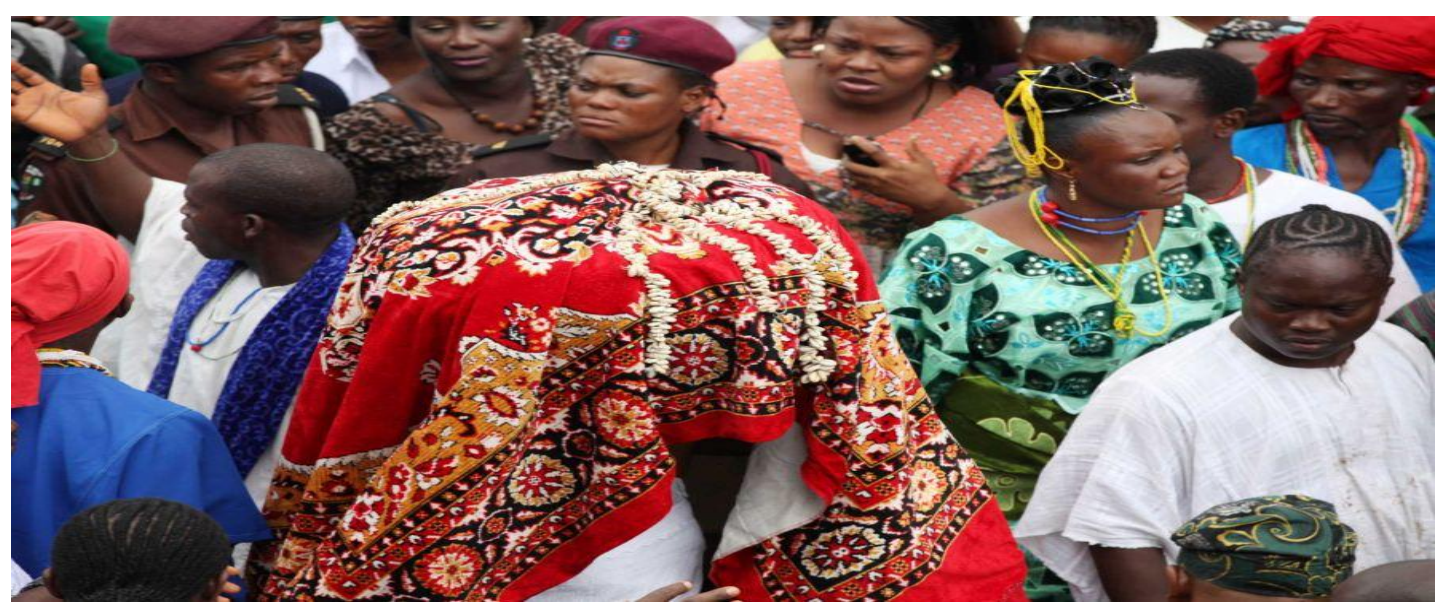

Worshipers of the Osun goddess make their way along with an unidentified virgin girl 'Arugba', centre, to the river in Osogbo, Nigeria.

Source: Chron (2012).

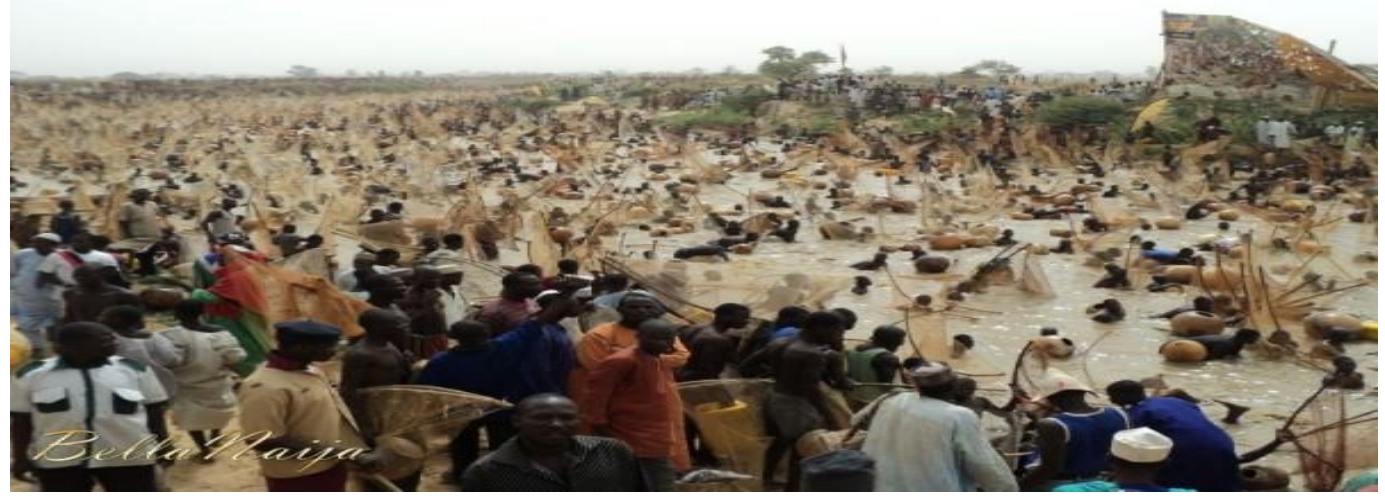

The Argungu Fishing Festival

The festival is the culmination of a four-day cultural event in the north-western Nigerian state of Kebbi. Thousands of fishermen line up like an ancient army, carrying their traditional nets and gourds. At the sound of a gun, they pound towards the narrow river and leap into the water.They have just one hour to catch the biggest fish. Source:Bella Naija (2012).

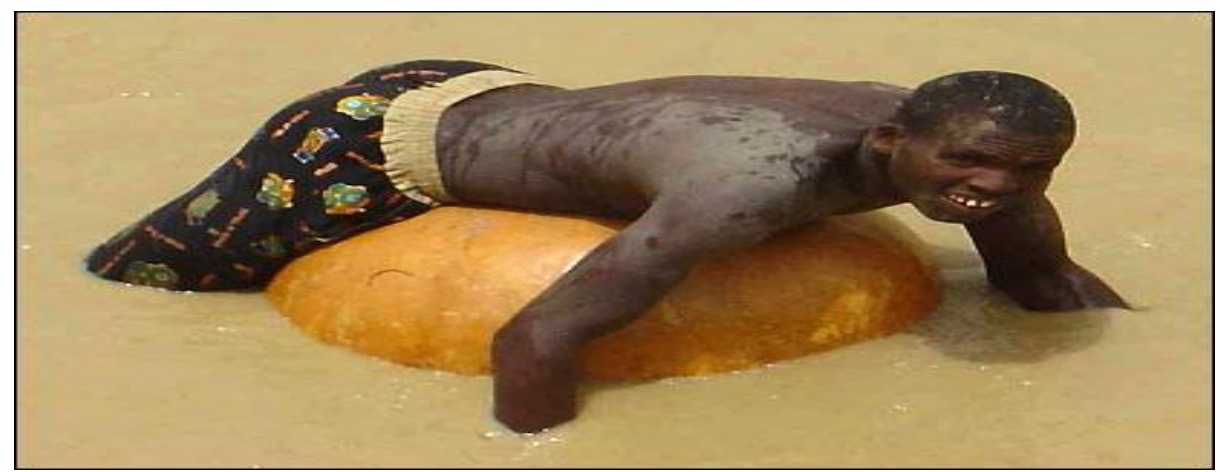

Fishing festival floating around

A man lies on his calabash - used for flotation, and to store fish - and waits for the speeches to finish. Source: BBC News (n.d.). 


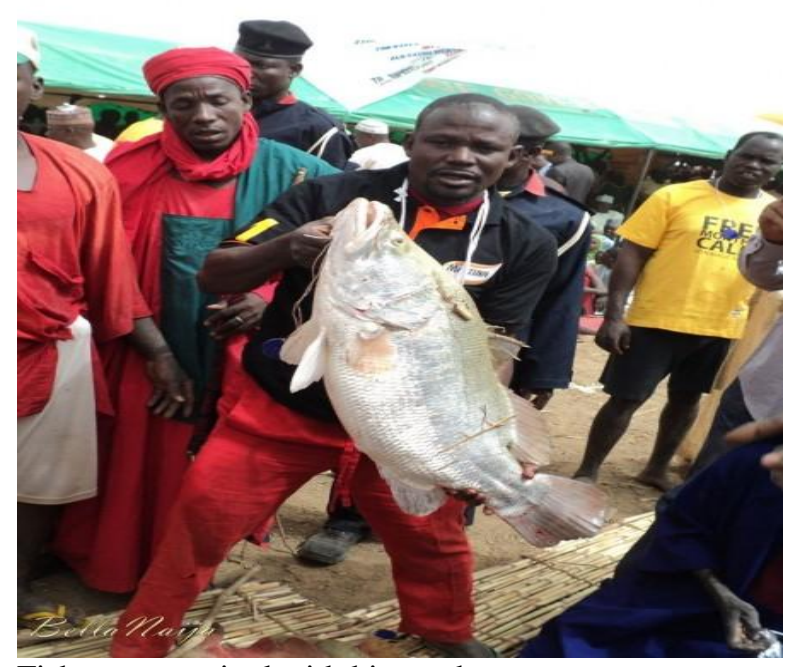

Fisherman excited with his catch

Source:BellaNaija (2012)

Table 1: Nigeria's Tourism Statistics (2000-2011)

\begin{tabular}{|c|c|c|c|c|c|c|c|}
\hline \multirow[t]{2}{*}{ year } & \multirow[t]{2}{*}{$\begin{array}{l}\text { Internat } \\
- \\
\text { ional } \\
\text { tourist } \\
\text { arrivals }\end{array}$} & \multirow[t]{2}{*}{$\begin{array}{l}\text { tourism } \\
\text { receipts( } \\
\text { \$) }\end{array}$} & \multirow{2}{*}{$\begin{array}{l}\text { receipts } \\
(\% \text { of } \\
\text { total } \\
\text { exports }) \\
\text { in } \\
\text { Nigeria }\end{array}$} & \multicolumn{2}{|c|}{$\begin{array}{l}\text { direct } \\
\text { contribution of } \\
\text { travel \& tourism } \\
\text { to GDP }\end{array}$} & \multicolumn{2}{|c|}{$\begin{array}{l}\text { direct contribution of travel \& tourism } \\
\text { to employment }\end{array}$} \\
\hline & & & & $\begin{array}{l}\text { Constant } \\
2011 \\
\text { NGNbn }\end{array}$ & $\begin{array}{l}\text { \% of } \\
\text { whole } \\
\text { econo } \\
\text { my } \\
\text { GDP }\end{array}$ & $\begin{array}{l}\text { '000 } \\
\text { jobs }\end{array}$ & $\begin{array}{l}\% \text { of whole economy } \\
\text { employment }\end{array}$ \\
\hline 2000 & 813,000 & $\begin{array}{l}186,000 \\
000\end{array}$ & 0.89 & - & - & - & - \\
\hline 2001 & 850,000 & $\begin{array}{l}168,000 \\
000\end{array}$ & 0.86 & - & - & - & - \\
\hline 2002 & 887,000 & $\begin{array}{l}256,000, \\
000\end{array}$ & 1.41 & 555.4 & 2.8 & $\begin{array}{l}1,038,0 \\
00\end{array}$ & 2.3 \\
\hline 2003 & 924,000 & $\begin{array}{l}58,000,0 \\
00\end{array}$ & 0.21 & 600.0 & 2.7 & $\begin{array}{l}1,100,0 \\
00\end{array}$ & 2.3 \\
\hline 2004 & 962,000 & $\begin{array}{l}49,000,0 \\
00\end{array}$ & 0.13 & 697.4 & 2.9 & $\begin{array}{l}1,170,0 \\
00\end{array}$ & 2.4 \\
\hline 2005 & $\begin{array}{l}1,010,00 \\
0\end{array}$ & $\begin{array}{l}139,000 \\
000\end{array}$ & 0.24 & 758.8 & 2.9 & $\begin{array}{l}1,196,0 \\
00\end{array}$ & 2.4 \\
\hline 2006 & $\begin{array}{l}1,111,00 \\
0\end{array}$ & $\begin{array}{l}209,000 \\
000\end{array}$ & 0.35 & 150.1 & 1.2 & 500,000 & 0.9 \\
\hline 2007 & $\begin{array}{l}1,212,00 \\
0\end{array}$ & $\begin{array}{l}337,000 \\
000\end{array}$ & 0.5 & 517.2 & 1.7 & 789,000 & 1.4 \\
\hline 2008 & $\begin{array}{l}1,313,00 \\
0\end{array}$ & $\begin{array}{l}959,000 \\
000\end{array}$ & 1.09 & 648.6 & 2.2 & $\begin{array}{l}1,039,0 \\
00\end{array}$ & 1.8 \\
\hline 2009 & $\begin{array}{l}1,414,00 \\
0\end{array}$ & $\begin{array}{l}791,000 \\
000\end{array}$ & 1.36 & 575.7 & 1.7 & 849,000 & 1.5 \\
\hline 2010 & $\begin{array}{l}1,450,00 \\
0\end{array}$ & $\begin{array}{l}738,000, \\
000\end{array}$ & 0.96 & 576.4 & 1.6 & 810,000 & 1.4 \\
\hline 2011 & $1,560,00$ & 738,000 & - & 598.6 & 1.6 & 838,500 & 1.4 \\
\hline
\end{tabular}




\begin{tabular}{ll}
\hline 0 & 000 \\
\hline
\end{tabular}

Source: World Development Indicators (2011), World Tourism Ranking(2011), W.T.T.C., ( 2012).

\begin{tabular}{llllllllll}
\hline Year & $\begin{array}{l}\text { External } \\
\text { Debt } \\
\text { (US\$ } \\
\text { million) }\end{array}$ & $\begin{array}{l}\text { GDP } \\
\text { per } \\
\text { capit } \\
\text { a } \\
\text { (US\$ } \\
\text { ) }\end{array}$ & $\begin{array}{l}\text { Life } \\
\text { Expectan } \\
\text { cy Rate at } \\
\text { Birth } \\
\text { age) }\end{array}$ & $\begin{array}{l}\text { Literacy } \\
\text { Rate } \\
(\boldsymbol{\%})\end{array}$ & $\begin{array}{l}\text { Populati } \\
\text { on below } \\
\text { Poverty } \\
\text { Line (\%) }\end{array}$ & $\begin{array}{l}\text { Labour } \\
\text { force } \\
\text { Growth } \\
\text { rate } \\
(\boldsymbol{\%})\end{array}$ & $\begin{array}{l}\text { Employ } \\
\text { ment } \\
\text { growth } \\
\text { rate (\%) }\end{array}$ & $\begin{array}{l}\text { Unemployme } \\
\text { nt Rate }(\%)\end{array}$ & $\begin{array}{l}\text { Inflation } \\
\text { rate (\%) }\end{array}$ \\
\hline 2000 & 29,000 & 970 & 51.56 & 57.10 & 28.00 & - & 41.1 & 34.10 & 6.9 \\
\hline 2001 & 32,000 & 950 & 51.07 & 57.10 & 28.00 & 1.5 & 43.6 & 45.00 & 18.9 \\
\hline 2002 & 32,000 & 840 & 50.59 & 57.10 & 0.28 & 1.6 & 44.8 & 45.00 & 12.9 \\
\hline 2003 & 29,700 & 875 & 51.01 & 68.00 & 28.00 & 2.8 & 46.8 & 60.00 & 22.2 \\
\hline 2004 & 31,070 & 900 & 50.49 & 68.00 & 5.60 & 1.9 & 47.8 & 60.00 & 15 \\
\hline 2005 & 30,550 & 1,000 & 46.74 & 68.00 & 5.60 & 5.8 & 49.6 & 60.00 & 17.9 \\
\hline 2006 & 32,450 & 1,400 & 47.08 & 68.00 & 2.90 & 2.6 & 52.0 & 60.00 & 8.2 \\
\hline 2007 & 6,280 & 1,500 & 47.44 & 68.00 & 5.80 & 2.9 & 53.9 & 60.00 & 5.9 \\
\hline 2008 & 8,010 & 2,100 & 46.53 & 68.00 & 4.90 & 1.8 & 55.0 & 70.00 & 11.5 \\
\hline 2009 & 8,320 & 2,100 & 46.94 & 68.00 & 4.90 & 2.0 & 55.3 & 70.00 & 11.6 \\
\hline 2010 & 11,020 & 1,224 & 51.40 & 66.00 & 60.9 & 2.1 & 55.5 & 21.1 & 13.8 \\
\hline 2011 & 56,300 & 2,069 & 51.90 & 66.60 & -62.8 & 2.0 & 55.4 & 23.9 & 10.9 \\
\hline
\end{tabular}

Table 2: Statistics of Economic Development Proxies in Nigeria

Source: World Bank Economic Statistics (n.d.);Nigeria Economic Fact Sheet (2012); Nigerian Institute of Social and Economic Research (NISER) (2008); This Day Live (2011); Trading Economics (2012;CBN Annual Reports and Statement of Account (various years); CBN Statistical Bulletin (2006); National Bureau of Statistics(2005).

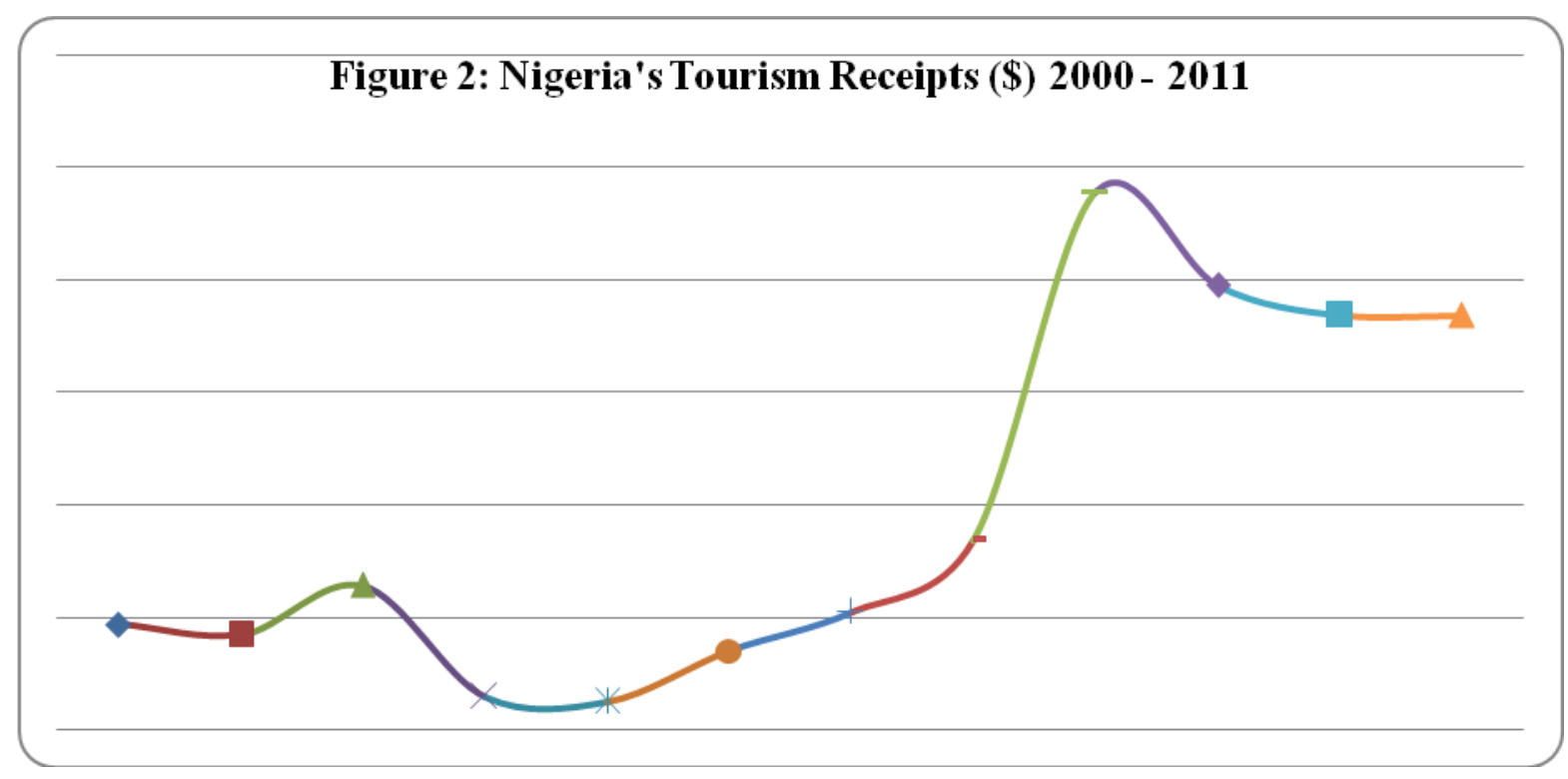

Source: World Development Indicators, World Tourism Ranking(2011), W.T.T.C., ( 2012). 
Table 3: List of Airports, Types and Location in Nigeria

\begin{tabular}{|c|c|c|c|c|}
\hline \multicolumn{5}{|c|}{ International Airports } \\
\hline Abuja & FCT & DNAA & $\mathrm{ABV}$ & NnamdiAzikiwe International Airport \\
\hline Kano & Kano & DNKN & KAN & MallamAminu Kano International Airport \\
\hline Lagos / Ikeja & Lagos & DNMM & LOS & MurtalaMuhammed International Airport \\
\hline $\begin{array}{l}\text { Port } \\
\text { Harcourt }\end{array}$ & Rivers & DNPO & PHC & Port Harcourt International Airport \\
\hline \multicolumn{5}{|c|}{ Major domestic airports } \\
\hline Calabar & $\begin{array}{l}\text { Cross } \\
\text { River }\end{array}$ & DNCA & CBQ & Margaret Ekpo International Airport (Calabar Airport) \\
\hline Enugu & Enugu & DNEN & ENU & AkanuIbiam International Airport (Enugu Airport) \\
\hline Jos & Plateau & DNJO & JOS & Yakubu Gowon Airport (Jos Airport) \\
\hline Kaduna & Kaduna & DNKA & KAD & Kaduna Airport \\
\hline Maiduguri & Borno & DNMA & MIU & Maiduguri International Airport (Maiduguri Airport) \\
\hline Sokoto & Sokoto & DNSO & SKO & $\begin{array}{l}\text { SadiqAbubakar III International Airport (Sultan SaddikAbubakar } \\
\text { Airport) }\end{array}$ \\
\hline Yola & Adamawa & DNYO & YOL & Yola Airport \\
\hline \multicolumn{5}{|c|}{ Other domestic airports } \\
\hline Asaba & Delta & DNAS & $\mathrm{ABB}$ & Asaba International Airport \\
\hline Akure & Ondo & DNAK & AKR & Akure Airport \\
\hline Bauchi & Bauchi & DNBA & $\mathrm{BCU}$ & Bauchi Airport \\
\hline Benin & Edo & DNBE & $\mathrm{BNI}$ & Benin Airport \\
\hline Gombe & Gombe & DNGO & & GombeLawanti International Airport \\
\hline Ibadan & Oyo & DNIB & IBA & Ibadan Airport \\
\hline Ilorin & Kwara & DNIL & ILR & Ilorin Airport \\
\hline Katsina & Katsina & DNKT & KTN & Katsina Airport \\
\hline Makurdi & Benue & DNMK & MDI & Makurdi Airport \\
\hline Minna & Niger & DNMN & MXJ & Minna Airport \\
\hline Owerri & Imo & DNIM & QOW & Sam Mbakwe Airport \\
\hline Warri & Delta & DNSU & QRW & Warri Airport \\
\hline Zaria & Kaduna & DNZA & ZAR & Zaria Airport \\
\hline \multicolumn{5}{|c|}{ Other airports not owned/managed by FAAN } \\
\hline Uyo & AkwaIbom & DNAI & & AkwaIbom Airport (Uyo Airport) \\
\hline
\end{tabular}

Source: World Tourism Ranking (2011).

Table 4: Some cases of religious violence in Nigeria, 1999-2012

\begin{tabular}{|c|c|c|c|c|}
\hline No & Date & State(s) & Nature & Remarks \\
\hline 1 & 1 Jul. 1999 & Ogun & $\begin{array}{l}\text { Violent clashes between Yoruba } \\
\text { traditional worshippers and } \\
\text { Hausa groups in Sagamu, Ondo } \\
\text { state. }\end{array}$ & $\begin{array}{l}\text { The crisis originated from the killing } \\
\text { of a Hausa woman by the Oro } \\
\text { Masqueraders for violating } \\
\text { traditional rites. }\end{array}$ \\
\hline 2 & $\begin{array}{l}21-22 \\
2000\end{array}$ & Kaduna & $\begin{array}{l}\text { Riots over the introduction of } \\
\text { Sharia (Islamic law). }\end{array}$ & An estimated 3000 people died. \\
\hline 3 & $\begin{array}{l}7-17 \\
2001\end{array}$ & Jos & $\begin{array}{l}\text { A religious riot between Muslims } \\
\text { and Christians in Jos. Mosques, } \\
\text { churches and several properties } \\
\text { were } \\
\text { damaged or torched. The clashes } \\
\text { started on September } 7 \text { and lasted } \\
\text { nearly two weeks, ending on } \\
\text { September } 17 \text {. }\end{array}$ & $\begin{array}{l}\text { The riot broke out when the Islamic } \\
\text { Brigade attacked a Christian woman } \\
\text { who attempted to cross a public } \\
\text { high-way barricaded by Muslim } \\
\text { worshippers on Friday. Over } 300 \\
\text { people were killed. }\end{array}$ \\
\hline
\end{tabular}




\begin{tabular}{|c|c|c|c|c|}
\hline 4 & 16 Nov. 2002 & Kaduna & $\begin{array}{l}\text { The Miss World crisis in which } \\
\text { Muslims } \\
\text { attacked Christians and churches. }\end{array}$ & $\begin{array}{l}\text { The crisis was triggered by an article } \\
\text { authored by Isioma Daniel in This } \\
\text { Day newspaper, alleging that } \\
\text { Prophet Mohammed would have } \\
\text { loved to have the girls. Over } 250 \\
\text { people were killed and several } \\
\text { churches destroyed. }\end{array}$ \\
\hline \multirow[t]{2}{*}{5} & \multirow[t]{2}{*}{8 Jun. 2004} & \multirow[t]{2}{*}{ Adamawa } & Religious conflict between & \multirow{2}{*}{$\begin{array}{l}\text { Caused by the location of the town's } \\
\text { Central Mosque close to Bachama } \\
\text { paramount ruler's palace. Over } 17 \\
\text { persons killed. }\end{array}$} \\
\hline & & & $\begin{array}{l}\text { Christians and Muslims in } \\
\text { Numan town. }\end{array}$ & \\
\hline 6 & 18 Feb. 2006 & Borno & $\begin{array}{l}\text { Religious conflict between } \\
\text { Christians } \\
\text { and Muslims in Maiduguri. }\end{array}$ & $\begin{array}{l}\text { The riot was caused by the Danish } \\
\text { cartoon on Prophet Mohammed, in } \\
\text { Jyllands-Posten newspaper. Over } 50 \\
\text { persons killed and } 30 \text { churches } \\
\text { destroyed; over } 200 \text { shops, } 50 \\
\text { houses and } 100 \text { vehicles vandalised. }\end{array}$ \\
\hline 7 & 22 Mar. 2007 & Gombe & $\begin{array}{l}\text { Muslim pupils killed their } \\
\text { Christian teacher, } \\
\text { MrsOluwatoyinOlusesan. }\end{array}$ & $\begin{array}{l}\text { The pupils claimed that their teacher } \\
\text { desecrated the Qur'an while } \\
\text { attempting to stop a student from } \\
\text { cheating in an examination hall. }\end{array}$ \\
\hline 8 & 28 Nov. 2008 & Plateau & $\begin{array}{l}\text { Religious violence between } \\
\text { Muslims and } \\
\text { Christians in the city of Jos. }\end{array}$ & $\begin{array}{l}\text { The crisis which was triggered by } \\
\text { the controversial results of a local } \\
\text { election later turned religious. Over } \\
700 \text { people killed and thousands } \\
\text { internally displaced. }\end{array}$ \\
\hline 9 & $\begin{array}{l}26-30 \\
2009\end{array}$ & $\begin{array}{l}\text { Bauchi, } \\
\text { Borno, } \\
\text { Kano, } \\
\text { Yobe }\end{array}$ & $\begin{array}{l}\text { Religious violence unleashed by } \\
\text { the radical Boko Haram sect on } \\
\text { Christians. }\end{array}$ & $\begin{array}{l}\text { Over } 700 \text { persons killed, } 3500 \\
\text { persons internally displaced, } 1264 \\
\text { children orphaned, over } 392 \text { women } \\
\text { widowed, and several properties } \\
\text { destroyed. }\end{array}$ \\
\hline 10 & 7 Mar. 2010 & Plateau & $\begin{array}{l}\text { Attacks by Fulani Moslems on } \\
\text { Christian dominated villages of } \\
\text { DogoNahawa, Shen and Fan in } \\
\text { Jos. }\end{array}$ & $\begin{array}{l}\text { Over } 500 \text { people - mainly women } \\
\text { and children - were killed. }\end{array}$ \\
\hline 11 & 29 Aug. 2011 & Plateau & $\begin{array}{l}\text { Clashes between Muslims and } \\
\text { Christians at Rukuba road and } \\
\text { FarinGada in Jos during the } \\
\text { Ramadan prayers. }\end{array}$ & $\begin{array}{l}\text { No less than } 20 \text { persons were killed, } \\
50 \text { injured, over } 50 \text { motor vehicles } \\
\text { and } 100 \text { motor cycles were torched. }\end{array}$ \\
\hline 12 & 5-6 Jan. 2012 & Gombe, & $\begin{array}{l}\text { Gunmen stormed a Deeper life } \\
\text { church in Gombe, shooting } \\
\text { indiscriminately at worshippers. } \\
\text { The BokoHaram Islamist sect } \\
\text { claimed responsibility for the } \\
\text { shooting. }\end{array}$ & $\begin{array}{l}6 \text { persons were reportedly killed } \\
\text { while many others were injured. }\end{array}$ \\
\hline
\end{tabular}

Source: Sampson (2012). 


\begin{tabular}{|c|c|c|c|}
\hline & & $\operatorname{tar}$ & tre \\
\hline \multirow[t]{3}{*}{$\operatorname{tar}$} & Pearson Correlation & 1 & $.861^{* * *}$ \\
\hline & Sig. (2-tailed) & & .000 \\
\hline & $\mathrm{N}$ & 12 & 12 \\
\hline \multirow[t]{3}{*}{ tre } & Pearson Correlation & $.861^{* *}$ & 1 \\
\hline & Sig. (2-tailed) & .000 & \\
\hline & $\mathrm{N}$ & 12 & 12 \\
\hline
\end{tabular}

**. Correlation is significant at the 0.01 level (2-tailed).

Source: Computed by Author using SPSS software 19.

\begin{tabular}{|c|c|c|c|c|c|c|}
\hline \multicolumn{7}{|c|}{ Table 6: Descriptive Statistics } \\
\hline \multicolumn{3}{|c|}{$\mathrm{N}$} & \multicolumn{2}{|c|}{ Minimum } & Maximum & Mean \\
\hline \multicolumn{2}{|l|}{$\operatorname{tar}$} & 12 & \multicolumn{2}{|c|}{813000.00} & 1560000.00 & 1125500.00 \\
\hline \multicolumn{2}{|l|}{ tre } & 12 & \multicolumn{2}{|c|}{49000000.00} & $9.59 \mathrm{E} 8$ & 3.8567 \\
\hline \multicolumn{2}{|c|}{ Valid N (listwise) } & 12 & & & & \\
\hline \multicolumn{7}{|c|}{ Source: Computed by Author using SPSS software 19.} \\
\hline \multicolumn{7}{|c|}{ Table 7: Frequency table for International Tourist Arrivals in Nigeria } \\
\hline \multicolumn{2}{|c|}{ Tourist Arrivals } & Freque & & Percent & $\begin{array}{c}\text { Valid } \\
\text { Percent }\end{array}$ & $\begin{array}{c}\text { Cumulative } \\
\text { Percent }\end{array}$ \\
\hline \multirow[t]{13}{*}{ Valid } & 813000.00 & & 1 & 7.7 & 8.3 & 8.3 \\
\hline & 850000.00 & & 1 & 7.7 & 8.3 & 16.7 \\
\hline & 887000.00 & & 1 & 7.7 & 8.3 & 25.0 \\
\hline & 924000.00 & & 1 & 7.7 & 8.3 & 33.3 \\
\hline & 962000.00 & & 1 & 7.7 & 8.3 & 41.7 \\
\hline & 1010000.00 & & 1 & 7.7 & 8.3 & 50.0 \\
\hline & 1111000.00 & & 1 & 7.7 & 8.3 & 58.3 \\
\hline & 1212000.00 & & 1 & 7.7 & 8.3 & 66.7 \\
\hline & 1313000.00 & & 1 & 7.7 & 8.3 & 75.0 \\
\hline & 1414000.00 & & 1 & 7.7 & 8.3 & 83.3 \\
\hline & 1450000.00 & & 1 & 7.7 & 8.3 & 91.7 \\
\hline & 1560000.00 & & 1 & 7.7 & 8.3 & 100.0 \\
\hline & Total & & 12 & 92.3 & 100.0 & \\
\hline $\begin{array}{l}\text { Missin } \\
\mathrm{g}\end{array}$ & System & & 1 & 7.7 & & \\
\hline Total & & & 13 & 100.0 & & \\
\hline
\end{tabular}

Source: Computed by Author using SPSS software 19.

\begin{tabular}{|c|c|c|c|c|c|}
\hline \multicolumn{2}{|c|}{ Tourism Receipts(\$) } & \multirow{2}{*}{$\begin{array}{r}\text { Frequency } \\
1 \\
\end{array}$} & \multirow{2}{*}{$\begin{array}{r}\text { Percent } \\
7.7 \\
\end{array}$} & \multirow{2}{*}{\begin{tabular}{r}
\multicolumn{1}{c}{$\begin{array}{c}\text { Valid } \\
\text { Percent }\end{array}$} \\
8.3 \\
\end{tabular}} & \multirow{2}{*}{$\begin{array}{l}\begin{array}{l}\text { Cumulative } \\
\text { Percent }\end{array} \\
\\
\end{array}$} \\
\hline Valid & 49000000.00 & & & & \\
\hline & 58000000.00 & 1 & 7.7 & 8.3 & 16.7 \\
\hline & 139000000.00 & 1 & 7.7 & 8.3 & 25.0 \\
\hline & 168000000.00 & 1 & 7.7 & 8.3 & 33.3 \\
\hline & 186000000.00 & 1 & 7.7 & 8.3 & 41.7 \\
\hline & 209000000.00 & 1 & 7.7 & 8.3 & 50.0 \\
\hline & 256000000.00 & 1 & 7.7 & 8.3 & 58.3 \\
\hline & 337000000.00 & 1 & 7.7 & 8.3 & 66.7 \\
\hline
\end{tabular}




\begin{tabular}{llrrrr}
\hline & 738000000.00 & 2 & 15.4 & 16.7 & 83.3 \\
\cline { 2 - 6 } & 791000000.00 & 1 & 7.7 & 8.3 & 91.7 \\
\cline { 2 - 6 } & 959000000.00 & 1 & 7.7 & 8.3 & 100.0 \\
\cline { 2 - 5 } & Total & 12 & 92.3 & 100.0 & \\
\hline Missing & System & 1 & 7.7 & & \\
\hline Total & & 13 & 100.0 & & \\
\hline
\end{tabular}

Source: Computed by Author using SPSS software 19.

\section{Copyrights}

Copyright for this article is retained by the author(s), with first publication rights granted to the journal. This is an open-access article distributed under the terms and conditions of the Creative Commons Attribution license (http://creativecommons.org/licenses/by/4.0/). 